\title{
Microstructure, Mechanical Properties, Abrasive Wear, and Corrosion Behavior in Molten Zinc of Boride-Based Coatings in Situ Synthesized by an HVOF Spraying Process
}

\author{
Xiao Chen ${ }^{1,2, *(1)}$, Chengdi Li ${ }^{1}$, Xiaobo Bai ${ }^{2}$, Hongtao Wang ${ }^{2}$, Shunjian $\mathrm{Xu}^{1}$ and Su Song ${ }^{1}$ \\ 1 Xinyu Key Laboratory of Materials Technology and Application for Intelligent Manufacturing, School of \\ Mechanical and Electrical Engineering, XinYu University, Xinyu 338004, China; \\ cd11988_xyxy@126.com (C.L.); wesdly@163.com (S.X.); SongSu_1979@163.com (S.S.) \\ 2 Jiangxi Province Engineering Research Center of Materials Surface Enhancing \& Remanufacturing, School of \\ Mechanical and Materials Engineering, Jiujiang University, Jiujiang 332005, China; \\ Xiaobo_Bai@126.com (X.B.); wanght_1976@163.com (H.W.) \\ * Correspondence: chenxiaoxyxy@126.com; Tel./Fax: +86-790-6666108
}

Received: 13 September 2019; Accepted: 11 October 2019; Published: 14 October 2019

check for updates

\begin{abstract}
Hot-dip galvanizing has been used for anti-corrosion of various steel products; however, the corrosion of molten zinc in the galvanizing industry is the key problem to be solved. Three kinds of Mo-B-Co-Cr, Mo-B-Ni-Cr, and Ti-B-Co-Cr mixture powders were deposited on the surface of a $316 \mathrm{~L}$ stainless-steel substrate by a HVOF spraying method to prepare $\mathrm{MoB} / \mathrm{CoCr}, \mathrm{MoB} / \mathrm{NiCr}$, and $\mathrm{TiB} / \mathrm{CoCr}$ coatings. The microstructure, mechanical properties, abrasive wear, and corrosion behavior in molten zinc of the in situ synthesized boride-based coatings were investigated. The experimental results showed that $\mathrm{MoB} / \mathrm{NiCr}$ coating with a denser microstructure had the lowest porosity $(0.811 \%)$. The in situ synthesized boride-phase compositions of $\mathrm{MoB} / \mathrm{CoCr}$, MoB/NiCr, and $\mathrm{TiB} / \mathrm{CoCr}$ coatings were $\mathrm{CoMoB}$ and $\mathrm{CoMo}_{2} \mathrm{~B}_{2}, \mathrm{NiMo}_{2} \mathrm{~B}_{2}$, and $\mathrm{TiB}_{2}$, respectively. The $\mathrm{MoB} / \mathrm{NiCr}$ coating had the highest boride content among the coatings. The presence of binary $\left(\mathrm{TiB}_{2}\right)$ or ternary boride phases $(\mathrm{CoMoB}$, $\mathrm{CoMo}_{2} \mathrm{~B}_{2}$, and $\mathrm{NiMo}_{2} \mathrm{~B}_{2}$ ) with their excellent mechanical properties could obviously increase the microhardness values in the coatings. The in situ synthesized borides in the coatings also could improve the wear resistance properties; $\mathrm{MoB} / \mathrm{NiCr}$ coating with shallower grooves and smaller craters/pits had the smoothest worn surface and the lowest weight loss $(6.8 \pm 0.84 \mathrm{mg})$ among the coatings. After immersion test in molten zinc for $360 \mathrm{~h}$, no presence of zinc or intermetallic compounds in the three kinds of the coatings $(\mathrm{MoB} / \mathrm{CoCr}, \mathrm{MoB} / \mathrm{NiCr}$, and $\mathrm{TiB} / \mathrm{CoCr})$, and the element compositions of the three kinds of coatings after the immersion test were the same as the as-sprayed coatings. Compared to the other coatings, $\mathrm{MoB} / \mathrm{NiCr}$ coatings had the higher durability in molten zinc.
\end{abstract}

Keywords: high velocity oxygen-fuel; boride; microstructure; microhardness; abrasive wear; corrosion resistance

\section{Introduction}

Hot-dip galvanizing used in anti-corrosion for various steel products has been widely used in the automobile and chemical industries, as well as metallurgy, construction, household appliances, national defense, and other industries [1,2]. However, the corrosion of molten zinc in galvanizing industry is a key problem to be solved [3-5]. The application of thermal sprayed coating materials (e.g., intermetallic compounds, cermets, and ceramics) on the steel substrate to prevent corrosion of molten zinc is a common method [6]. Yan et al. [6,7] reported that the order of corrosion resistance of 
$\mathrm{Fe}-\mathrm{Al}$ intermetallic compound coatings prepared by plasma spraying was $\mathrm{FeAl}>\mathrm{Fe}_{2} \mathrm{Al}_{5}>\mathrm{FeAl}_{2}$; an $\mathrm{Fe}_{2} \mathrm{Al}_{5}$ coating could hinder the corrosion of molten zinc to a certain extent. However, the micro-cracks generated in the $\mathrm{Fe}-\mathrm{Al}$ coating as the immersion test time increased. Dong et al. [8] reported that the lifetime of the substrate coated with $\mathrm{ZrO}_{2}-\mathrm{Ni} / \mathrm{Al}$ gradient coatings was four times longer than that of the general $\mathrm{ZrO}_{2}$ coating; however, zinc atoms could diffuse into the pores and grain boundaries of $\mathrm{ZrO}_{2}$ coating and react with the Ni/Al gradient transition layer. Seong et al. [9] reported that WC (Please define if appropriate)-Co cermet coatings with $\mathrm{Co}-\mathrm{W}-\mathrm{C}$ ternary binders could reduce the depth of zinc diffusion into the Co binder phase. However, Al-Fe corrosion layers were observed on the surface of WC-12Co coating and in the micro-cracks generated in the coating. Tomita et al. $[10,11]$ revealed that WC-12Co coating with ternary $\mathrm{Co}_{3} \mathrm{~W}_{3} \mathrm{C}$ and $\mathrm{Co}_{6} \mathrm{~W}_{6} \mathrm{C}$ phases could improve the corrosion resistance to molten zinc, however, zinc also could react with the WC-12Co coating. Mizuno et al. [12] also reported that the corrosion resistance property of WC-Co coatings increased as the $\mathrm{Co}_{3} \mathrm{~W}_{3} \mathrm{C}$ and $\mathrm{Co}_{6} \mathrm{~W}_{6} \mathrm{C}$ ternary phases increased and the free Co content decreased.

Boride ceramic is an attractive material, which is widely applied to anti-corrosion (die-casting) or wear resistance industries because of its higher melting point, hardness, and elastic modulus, as well as its greater oxidation, wear, or erosion resistance than metallic materials, especially ternary borides (e.g., $\mathrm{CoMo}_{2} \mathrm{~B}_{2}, \mathrm{CoMoB}$, and $\mathrm{NiMo}_{2} \mathrm{~B}_{2}$ ) or binary borides $\left(\mathrm{TiB}_{2}\right.$ ) [13-15]. Therefore, some researchers have adopted a series of thermal spraying methods (e.g., high-velocity oxygen fuel (HVOF), LPPS, DS, etc.) to deposit $\mathrm{MoB} / \mathrm{CoCr}$ [13,16-19], $\mathrm{MoB} / \mathrm{NiCr}$ [13,20], and $\mathrm{TiB}_{2}-\mathrm{M}$ [21-23] coatings, which protect the casting components against erosion and abrasive.

High-velocity oxygen fuel (HVOF) spraying, considered to have the best economic and industrial value, has been widely adopted in many machinery manufacturing industries [13,24]. The coatings prepared by the HVOF spraying process have good coating properties, such as relatively low porosity, good bond strength, high microhardness, and anti-corrosion or wear resistance [24,25]. Therefore, the literature has reported that $\mathrm{MoB} / \mathrm{CoCr}$ and $\mathrm{MoB} / \mathrm{NiCr}$ coatings, as novel cermet materials possessed ternary boride (e.g., $\mathrm{Co}-\mathrm{Mo}-\mathrm{B}$ or $\mathrm{Ni}-\mathrm{Mo}-\mathrm{B}$ ) structures for thermal spraying, have outstanding performance with features like high durability and no wettability in molten aluminum alloys or pure zinc. Khan et al. [13] reported that, due to the existence of multiple inert borides $\left(\mathrm{Cr}_{2} \mathrm{Ni}_{3} \mathrm{~B}_{6}\right.$, $\mathrm{CoMo}_{2} \mathrm{~B}_{2}$, and $\mathrm{CoMoB}$ ) in the coatings, the MoB-based cermet coatings have low wettability with molten alloy. Therefore, the MoB-based cermet coatings have shown higher soldering resistance, as negligible intermetallic formation occurred during the immersion test. Meanwhile, the $\mathrm{MoB} / \mathrm{NiCr}$ coating with higher microstructural properties in terms of coating density and porosity had higher wear resistance and durability than that of $\mathrm{MoB} / \mathrm{CoCr}, \mathrm{NiCr}$, and $\mathrm{CoMoCr}$ coatings. Mizuno et al. [16] also reported that the $\mathrm{MoB} / \mathrm{CoCr}$ cermet coatings, due to no wettability in molten alloys and the double boride structure in the coatings, had excellent durability in the molten $\mathrm{Al}-45 \mathrm{wt} \% \mathrm{Zn}$ alloy compared to WC-12 wt \% Co, $\mathrm{Al}_{2} \mathrm{O}_{3}$, and $\mathrm{ZrO}_{2}-8$ wt $\% \mathrm{Y}_{2} \mathrm{O}_{3}$ coatings. Lv et al. $[17,26]$ reported that $\mathrm{MoB} / \mathrm{CoCr}$ coatings has excellent mechanical properties because of the formation of ternary boride hard phases $\left(\mathrm{CoMo}{ }_{2} \mathrm{~B}_{2}\right.$ and $\left.\mathrm{CoMoB}\right)$ in the coating. An $\mathrm{MoB} / \mathrm{CoCr}$ coating as an alternative to a WC-12Co coating had higher durability with a longer lifetime and better thermal shock property than that of a WC-Co coating [19]. $\mathrm{TiB}_{2}$ is a potential material with outstanding mechanical and anti-corrosion properties. The microstructure, thermal shock, and molten $\mathrm{Al}$ alloy corrosion resistance of $\mathrm{TiB}_{2}-\mathrm{Ni}$ coatings with different binder phase contents deposited by HVOF have been investigated [23]. The results revealed that $\mathrm{TiB}_{2}-\mathrm{Ni}$ coatings had good performance in thermal shock resistance and excellent durability in the molten A-12.07 wt \% Si alloy. However, there would appear some micro-cracks in the coatings without the bond layer, which was attributed to the residual stress in the coating and the coefficient of thermal expansion (CTE) difference between the cermet coating and the substrate [13,16,19].

Although certain investigations about thermal-sprayed $\mathrm{MoB} / \mathrm{CoCr}, \mathrm{MoB} / \mathrm{NiCr}$, and $\mathrm{TiB}_{2}-\mathrm{M}$ coatings has been studied, the expensive cost of $\mathrm{MoB} / \mathrm{CoCr}$ and $\mathrm{MoB} / \mathrm{NiCr}$ have limited their industry application, and the problem of the interfacial bonding between borides and metal matrices is worth further studying. Therefore, in order to reduce cost and improve the interfacial bonding between 
borides and metal particles, the boride-based coatings ( $\mathrm{Co}-\mathrm{Mo}-\mathrm{B}, \mathrm{Ni}-\mathrm{Mo}-\mathrm{B}$, and $\mathrm{TiB}_{2}$ ) have been in situ synthesized by HVOF spraying technology in this study. Meanwhile, in contrast, the microstructure, mechanical properties, and abrasive wear, as well as corrosion resistance to molten zinc of the in situ synthesis of boride-based coatings have been investigated.

\section{Materials and Methods}

\subsection{Powder and Coating Preparation}

Figure 1 shows the surface and cross-sectional morphologies of all of the powders. Commercially available pure powders, including Mo $(99.9 \mathrm{wt} \%, \mathrm{D} 10=15.1 \mu \mathrm{m}, \mathrm{D} 50=43.2 \mu \mathrm{m}, \mathrm{D} 90=91.2 \mu \mathrm{m}$; Beijing DK Nano Technology Co., Ltd., Beijing, China), B (99.9 wt \%, D10 = $14.2 \mu \mathrm{m}$, D50 $=28.7 \mu \mathrm{m}$, D90 $=56.7 \mu \mathrm{m}$; Beijing DK Nano Technology Co., Ltd., Beijing, China), Co (99.9 wt \%, D10 = $1.03 \mu \mathrm{m}$, D50 = $10.8 \mu \mathrm{m}$, D90 = $56.6 \mu \mathrm{m}$; Beijing DK Nano Technology Co., Ltd., Beijing, China), Cr (99.9 wt \%, D10 $=3.18 \mu \mathrm{m}, \mathrm{D} 50=31.0 \mu \mathrm{m}, \mathrm{D} 90=58.2 \mu \mathrm{m}$; Beijing DK Nano Technology Co., Ltd., Beijing, China), Ni (99.8 wt \%, D10 $=20.8 \mu \mathrm{m}, \mathrm{D} 50=30.5 \mu \mathrm{m}$, D90 $=44.7 \mu \mathrm{m}$; BGRIMM Advanced Materials Science and Technology Co., Ltd., Beijing, China), and Ti (99.9 wt \%, D10 = $8.72 \mu \mathrm{m}, \mathrm{D} 50=25.0 \mu \mathrm{m}$, D90 = $50.7 \mu \mathrm{m}$; Beijing DK Nano Technology Co., Ltd., Beijing, China) were used as raw materials in this study. The particle size distribution of the powders is shown in Figure 2. Figure 3 shows the phase compositions of the powders; the phase composition of $\mathrm{B}$ powder cannot be displayed because $\mathrm{B}$ is a light element. Four kinds of pure powders, such as $\mathrm{Mo}, \mathrm{B}, \mathrm{Co}$, and $\mathrm{Cr} ; \mathrm{Mo}, \mathrm{B}, \mathrm{Ni}$, and $\mathrm{Cr}$; or $\mathrm{Ti}, \mathrm{B}, \mathrm{Co}$, and $\mathrm{Cr}$ were mixed by ball milling method at a rotation speed of $200 \mathrm{rpm}$ for $3 \mathrm{~h}$ to prepare $\mathrm{Mo}-\mathrm{B}-\mathrm{Co}-\mathrm{Cr}$, Mo-B-Ni-Cr, or Ti-B-Co-Cr mixture powders. The ball to powder weight ratio was 10:1. Then, the mixture powders, which were agglomerated in polyvinyl alcohol (PVA) binder solution, were crushed and sieved after drying to obtain the necessary thermal spraying particles. The details matching the mixture powders are shown in Table 1. The size distribution of pure and mixture powders were measured by a laser diffraction meter (Malvern Mastersizer 2000, Malvern instrument Ltd., Scotland, UK).
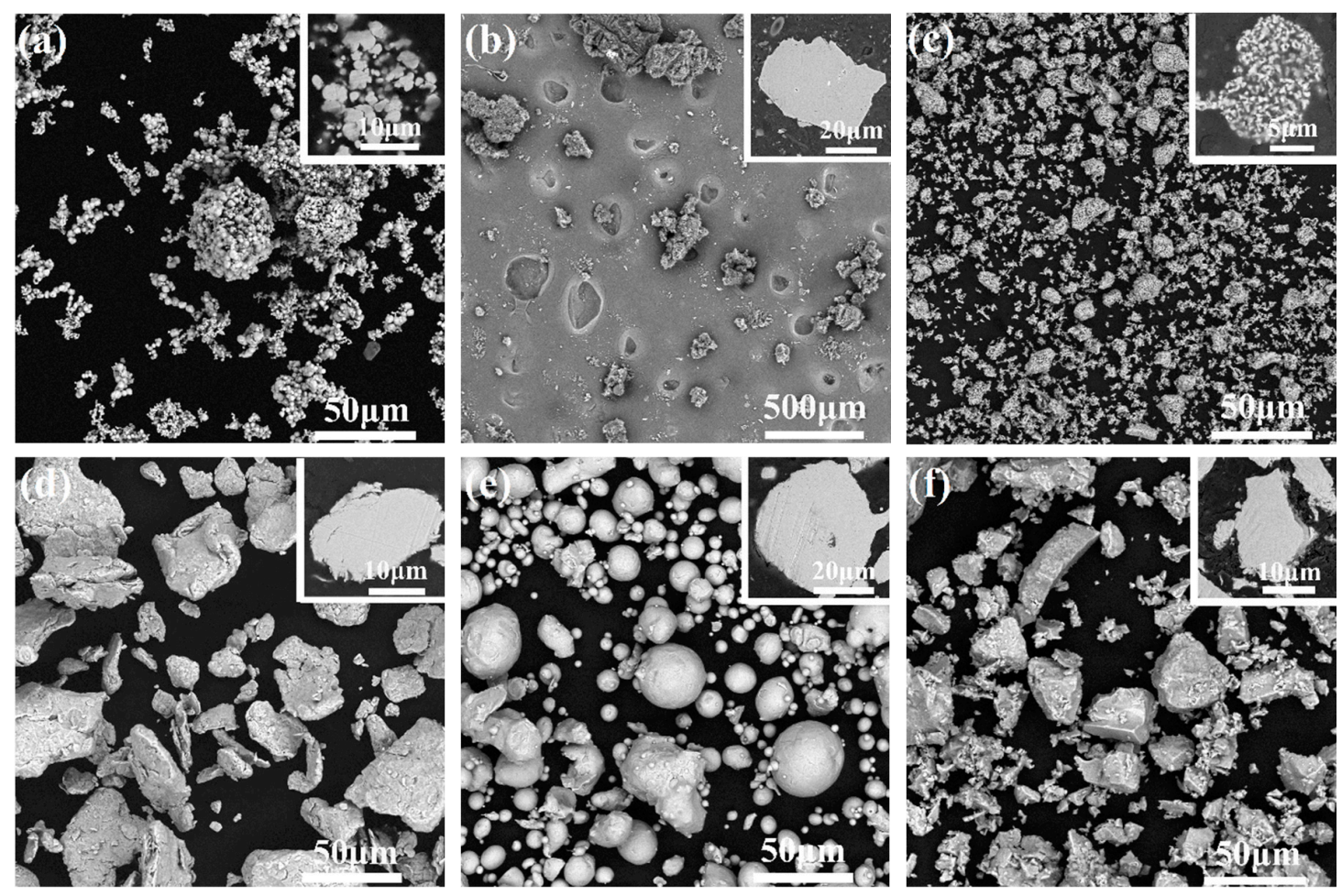

Figure 1. The surface and cross-sectional morphologies of the powders: (a) Mo, (b) B, (c) Co, (d) Cr, (e) $\mathrm{Ni}$, and (f) Ti. 

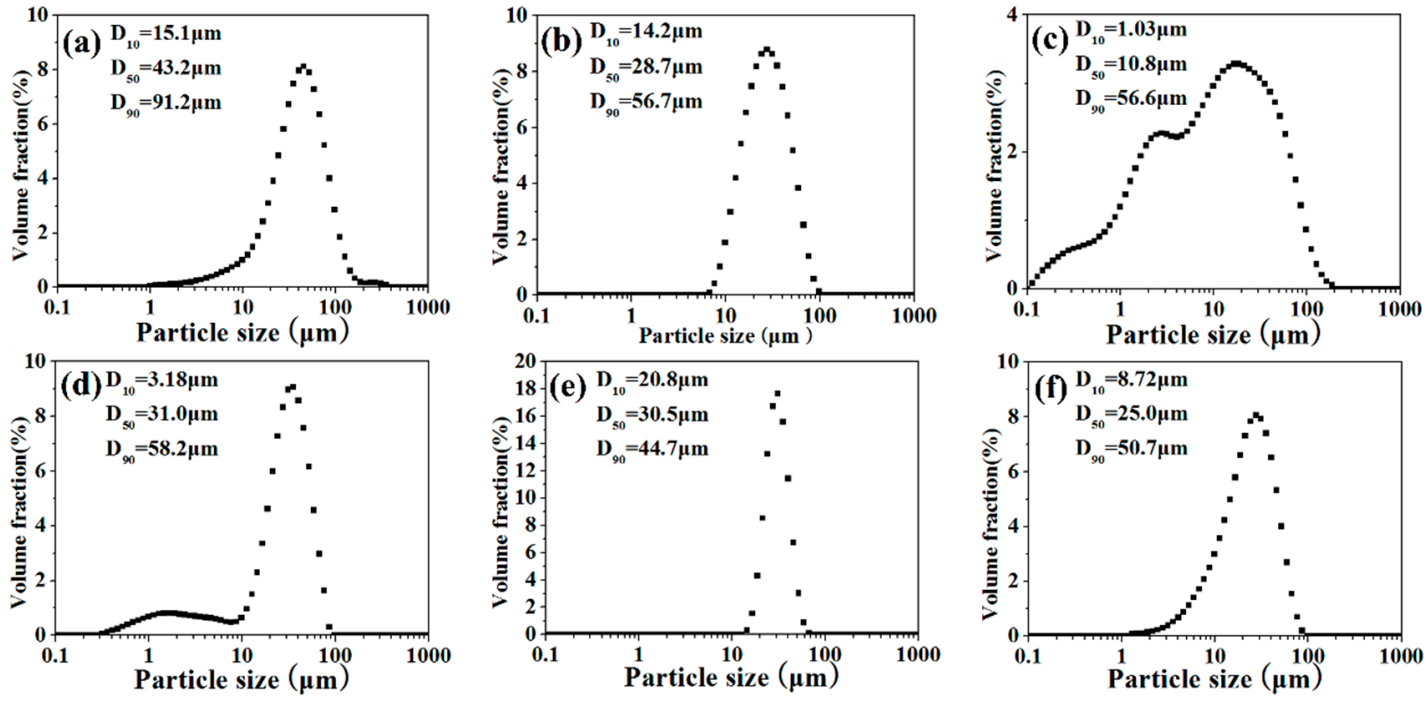

Figure 2. The particle size distribution of the powders: (a) Mo, (b) B, (c) Co, (d) Cr, (e) Ni, and (f) Ti.
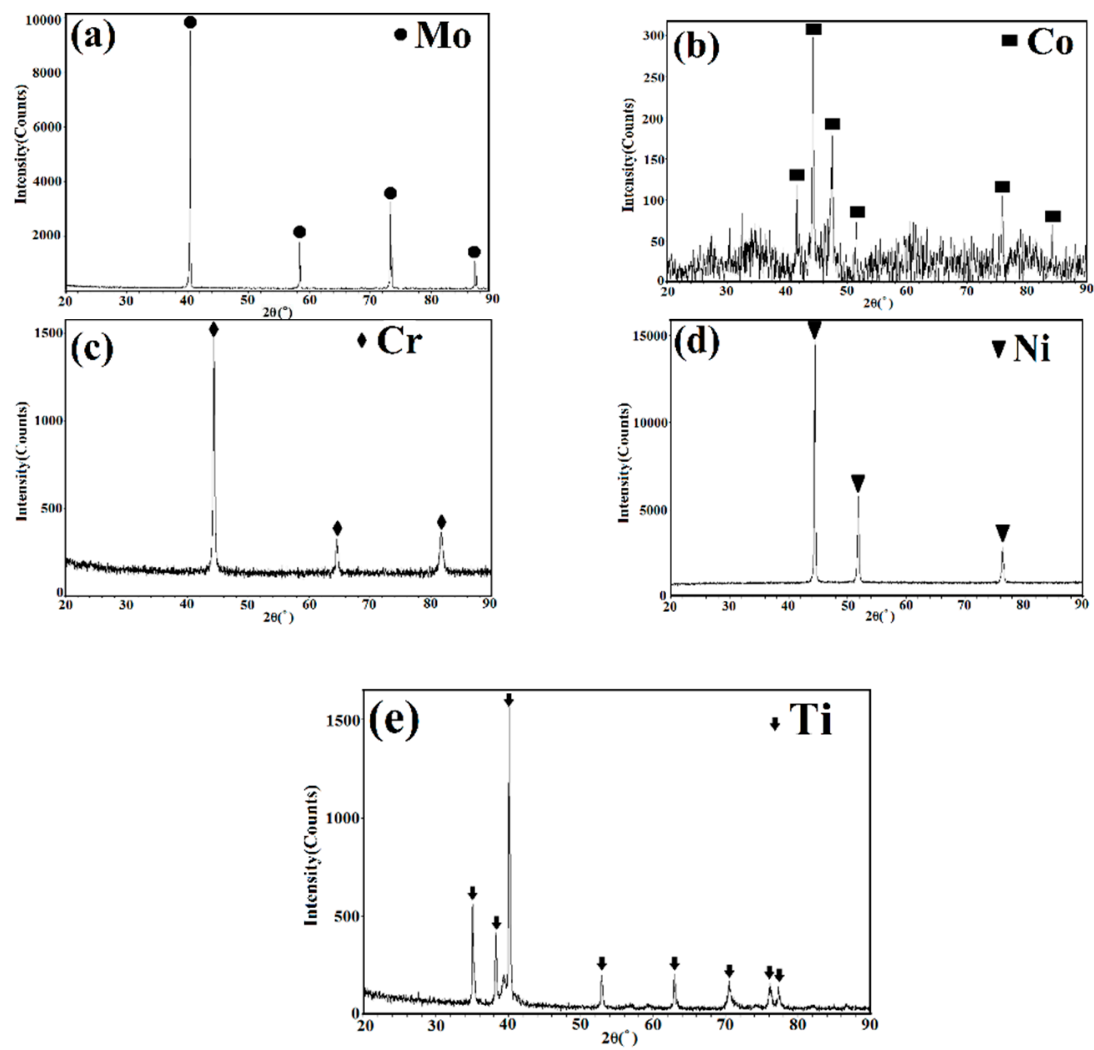

Figure 3. The phase compositions of the powders: (a) $\mathrm{Mo}$, (b) $\mathrm{Co},(\mathbf{c}) \mathrm{Cr}$, (d) $\mathrm{Ni}$, and (e) Ti.

Table 1. The details matching the mixture powders.

\begin{tabular}{ccc}
\hline Mixture Powder & Atomic Ratio & Mass Ratio \\
\hline Mo-B-Co-Cr & $\begin{array}{l}\text { at } \%_{\mathrm{Mo}} \text { :at } \%_{\mathrm{B}}=1: 1 \\
\text { at }{ }_{\mathrm{Co}}: \text { at } \%_{\mathrm{Cr}}=1: 1\end{array}$ & $m_{(\mathrm{Mo}+\mathrm{B})}: m_{(\mathrm{Co}+\mathrm{Cr})}=1: 1$ \\
at $\%_{\mathrm{Mo}}:$ at $\%_{\mathrm{B}}=1: 1$ & $m_{(\mathrm{Mo}+\mathrm{B})}: m_{(\mathrm{Ni}+\mathrm{Cr})}=1: 1$ \\
Mo-B-Ni-Cr & $\begin{array}{l}\text { at } \%_{\mathrm{Ni}}: \text { at } \%_{\mathrm{Cr}}=1: 1 \\
\text { at } \%_{\mathrm{Ci}}: \text { at } \%_{\mathrm{B}}=1: 1\end{array}$ & $m_{(\mathrm{Ti}+\mathrm{B})}: m_{(\mathrm{Co}+\mathrm{Cr})}=1: 1$ \\
Ti-B-Co-Cr & at $\%_{\mathrm{Co}}:$ at $\%_{\mathrm{Cr}}=1: 1$ & \\
\hline
\end{tabular}


A 316L stainless steel as a substrate with a size of $50 \mathrm{~mm} \times 25 \mathrm{~mm} \times 3 \mathrm{~mm}$ prior to spraying was grit-blasted using 24 mesh aluminum oxide. The mixture powders mentioned above were deposited on the surface of the substrate by a high-velocity oxygen fuel spray system $(\mathrm{CH}-2000)$ developed at $\mathrm{Xi}^{\prime}$ an Jiaotong University ( $\mathrm{Xi}^{\prime}$ an, China). The spray parameters of the HVOF spray coatings are listed in Table 2.

Table 2. The spray parameters of high-velocity oxygen fuel (HVOF) sprayed coatings.

\begin{tabular}{cc}
\hline Spray Parameters & Values \\
\hline Oxygen flow rate $(\mathrm{L} / \mathrm{min})$ & 402 \\
Fuel (propane) flow rate $(\mathrm{L} / \mathrm{min})$ & 36 \\
Carrier gas (nitrogen) flow rate $(\mathrm{L} / \mathrm{min})$ & 45 \\
Powder feed rate $(\mathrm{r} / \mathrm{min})$ & 50 \\
Stand-off distance $(\mathrm{mm})$ & 200 \\
Oxygen pressure $(\mathrm{MPa})$ & 0.6 \\
Fuel (propane) pressure $(\mathrm{Mpa})$ & 0.4 \\
Carrier gas (nitrogen) $(\mathrm{Mpa})$ & 0.55 \\
\hline
\end{tabular}

\subsection{Microhardness, Bond Strength and Abrasive Wear Testing}

The microhardness of as-sprayed coatings was measured on polished cross-sections using an HXD-1000 TM/LCD microhardness tester (Shanghai Precision Instruments Co., Ltd., Shanghai, China), with a $2.94 \mathrm{~N}$ load and $20 \mathrm{~s}$ dwell time. The microhardness value of the coatings was in the mean of a random 10 indents. The bond strength of as-sprayed coatings was measured with an ASTM C633-79 standard test method [27] using a standard tensile tester (TY 8000, Shanghai Bairui Mechanical Electrical Equipment Co., Ltd., Shanghai, China). The bond strength of the coatings was evaluated by the average value of three testing results. Abrasive wear testing of the coatings was examined using a pin-on-disk tester (ML-100, Zhangjiakou Chengxin Shiyan Equipment Manufacture Co., Ltd., Zhangiiakou, China). Figure 4 shows a schematic diagram of pin-on-disk wear testing in this study. The preparation for pin-on-disk wear specimens has been described in detail in [23]. The wear parameters of the coatings are listed in Table 3.

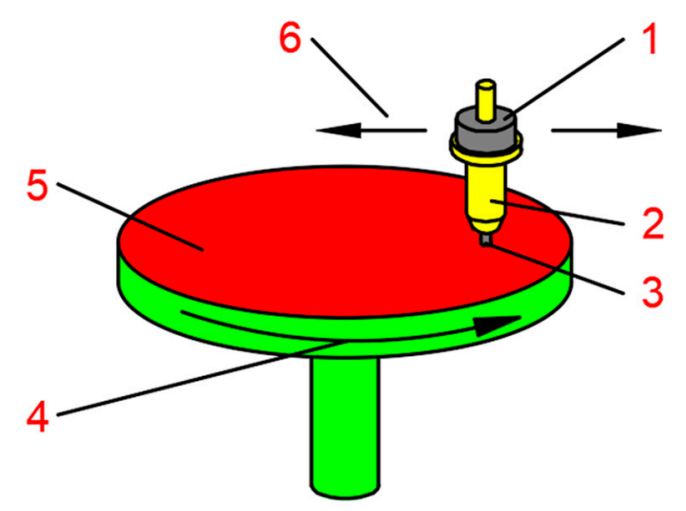

Figure 4. Schematic diagram of pin-on-disk wear testing: (1) weight, (2) clamp, (3) sample, (4) rotating direction of the disk, (5) abrasive paper, and (6) moving direction of the sample.

Table 3. The wear parameters of the coatings.

\begin{tabular}{cc}
\hline Wear Parameters & Values \\
\hline Applied load $(\mathrm{N})$ & 6 \\
Wear distance $(\mathrm{m})$ & 16 \\
Rotation speed of the disk $(\mathrm{r} / \mathrm{min})$ & 60 \\
Radial feed rate of the pin $(\mathrm{mm} / \mathrm{r})$ & 4 \\
SiC abrasive paper & 400 grit size \\
\hline
\end{tabular}




\subsection{Immersion Test in the Molten Zinc}

Figure 5 shows a schematic diagram of molten zinc immersion tester. Specimens were statically immersed in molten zinc at temperatures of $460 \pm 5{ }^{\circ} \mathrm{C}$ for $360 \mathrm{~h}$. The temperature of the furnace was measured by the thermocouple ((2) in the schematic diagram), as was that of molten zinc ((3) in the schematic diagram). The thermocouple from corrosion by molten zinc was protected by a quartz sleeve. After the set time, the specimens were taken out of the molten zinc for analysis. The zinc attached on the surface of the coating specimens was removed by $10 \mathrm{vol} \% \mathrm{HCl}$ solution.

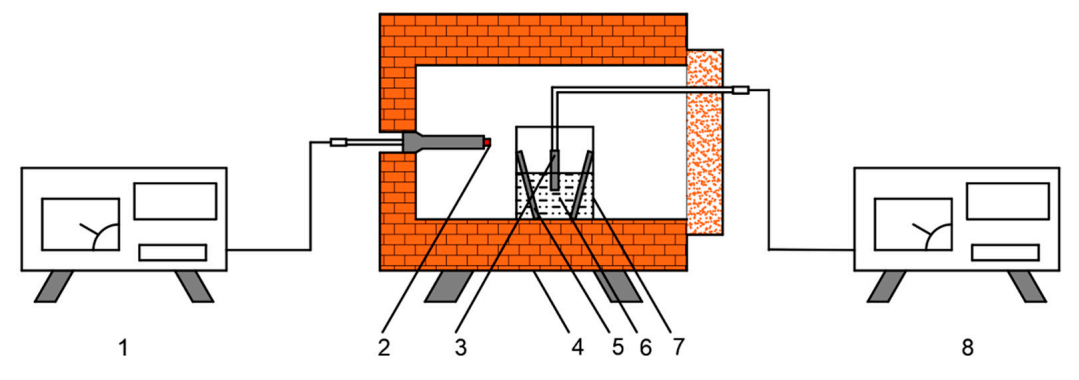

Figure 5. Schematic diagram of molten $\mathrm{Zn}$ immersion tester: $(1,8)$ temperature control; $(2,3)$ thermocouple, (4) furnace, (5) specimen, (6) molten $\mathrm{Zn}$, and (7) graphite crucible.

\subsection{Microstructure Characterization of the Powders and Coatings before and after Abrasive Wear and Corrosion}

The surface and cross-sectional morphologies of the powders, as well as the morphologies of the coatings before and after abrasive wear and corrosion were observed by scanning electron microscopy (SEM; VEGA II-LSU, TESCAN, Brno, Czech Republic) equipped with energy-dispersive spectroscopy (EDS) in back-scattered electron (BSE) imaging mode. X-ray diffraction (XRD, Bruker D8 Advance, Karlsruhe, Germany) with $\mathrm{Cu} \mathrm{K \alpha}(\lambda=1.5418 \AA)$ operated at $35 \mathrm{kV}$ and $35 \mathrm{~mA}$ was utilized to analyze the phase structure of the powders and the coatings. The average porosity of mixture powders and coatings, as well as the thickness of the coatings were measured by the image analysis method (Software Image J, version 1, National Institutes of Health, Bethesda, MD, USA) using five SEM micrographs from cross-section morphologies and backscattered electron (BSE) microscopies. The average crater content of the worn-out surface of the coatings was counted by using ten SEM micrographs from surface morphologies and backscattered electron (BSE) microscopies at the same magnification. The boride contents of the coatings were counted by using five SEM micrographs from cross-sectional morphologies and backscattered electron (BSE) microscopies at the same magnification.

\section{Results and Discussion}

\subsection{Morphologies, Size Distribution, and X-ray Diffraction Patterns of Mixture Powders}

Figure 6 shows the surface and cross-sectional morphologies of Mo-B-Co-Cr, Mo-B-Ni-Cr, and Ti-B-Co-Cr mixture powders. It can be observed that the surface morphologies of three kinds of the mixture powders were nearly spherical, which contributes to powder fluidity in the HVOF spraying process. Meanwhile, the average porosities of the Mo-B-Co-Cr, Mo-B-Ni-Cr, and Ti-B-Co-Cr mixture powders were $1.25 \%, 1.31 \%$, and $0.89 \%$, respectively. This illustrates that the mixture powders had a dense microstructure, due to the role of the PVA binder (as indicated by arrows in Figure 6a-c). The particle size distribution of the mixture powders was shown in Figure 7. It can be seen that the size distribution $\left(\mathrm{D}_{50}\right)$ of the Mo-B-Co-Cr, Mo-B-Ni-Cr, and Ti-B-Co-Cr mixture powders was $51.0 \mu \mathrm{m}$, $31.3 \mu \mathrm{m}$, and $41.0 \mu \mathrm{m}$, respectively. XRD patterns of the mixture powders (as shown in Figure 8) indicated that the phase compositions of the mixture powders were those of pure powder; this revealed that no oxidation, interaction, and introduction of impurities occurred during the ball milling of the powders. By comparing with the raw materials (as shown in Figure 1) after ball milling, it can be found that obvious plastic deformation occurred in every pure powder (Mo, B, Co, Ni, Cr, Ti) to form 
finer particle (as shown in Figure $6 \mathrm{~d}-\mathrm{f}$ ). In order to further characterize the plastic deformation of pure powders during ball milling, the full width at half maximum (FWHM) of the $\mathrm{Mo}, \mathrm{B}, \mathrm{Co}, \mathrm{Ni}, \mathrm{Cr}$, and $\mathrm{Ti}$ diffraction peaks in both the pure and mixture powders (Mo-B-Co-Cr, Mo-B-Ni-Cr, and Ti-B-Co-Cr) were estimated from XRD data, and are listed in Figure 9. It can be seen that the FWHMs of the Mo, B, $\mathrm{Co}, \mathrm{Ni}, \mathrm{Cr}$, and Ti diffraction peaks in the mixture powders were larger than those of pure powders, which indicates that particles underwent a certain plastic deformation upon high-speed impact during ball milling.
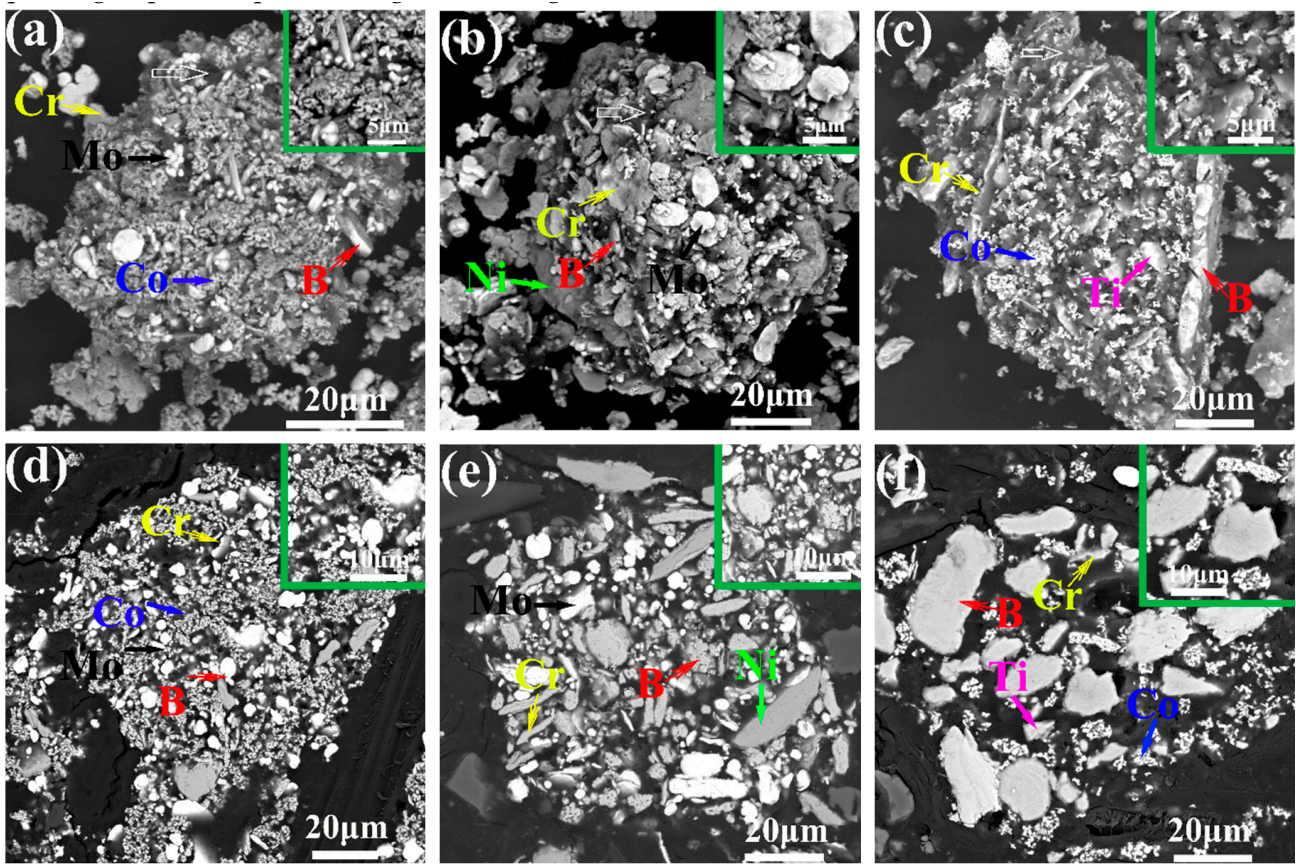

Figure 6. The surface and cross-sectional morphologies of mixture powders $(\mathbf{a}, \mathbf{d}) \mathrm{Mo}-\mathrm{B}-\mathrm{Co}-\mathrm{Cr} ;(\mathbf{b}, \mathbf{e})$ $\mathrm{Mo}-\mathrm{B}-\mathrm{Ni}-\mathrm{Cr}$; and (c,f) Ti-B-Co-Cr respectively.
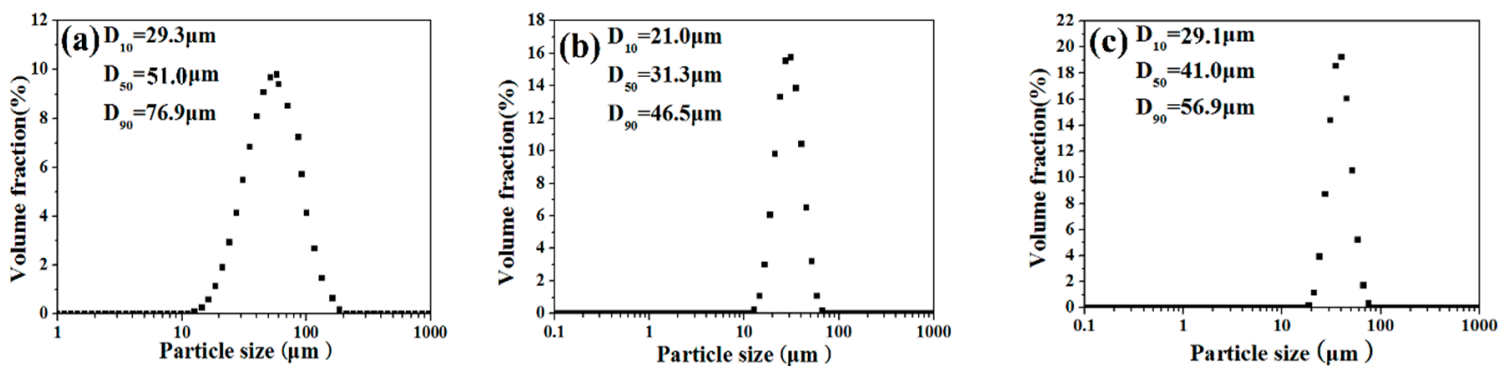

Figure 7. The size distributions and XRD patterns of mixture powders (a) Mo-B-Co-Cr, (b) Mo-B-Ni-Cr, and (c) Ti-B-Co-Cr.
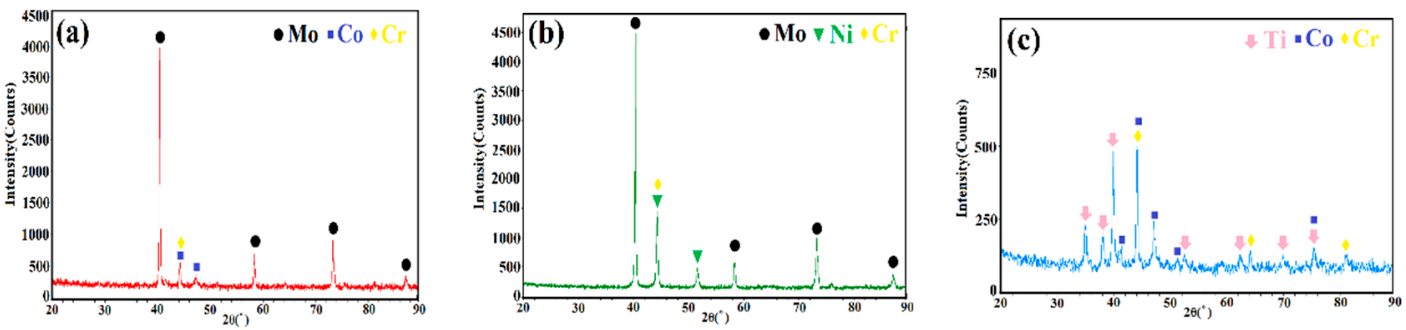

Figure 8. The X-ray diffraction (XRD) patterns of mixture powders (a) Mo-B-Co-Cr, (b) Mo-B-Ni-Cr, and (c) Ti-B-Co-Cr. 


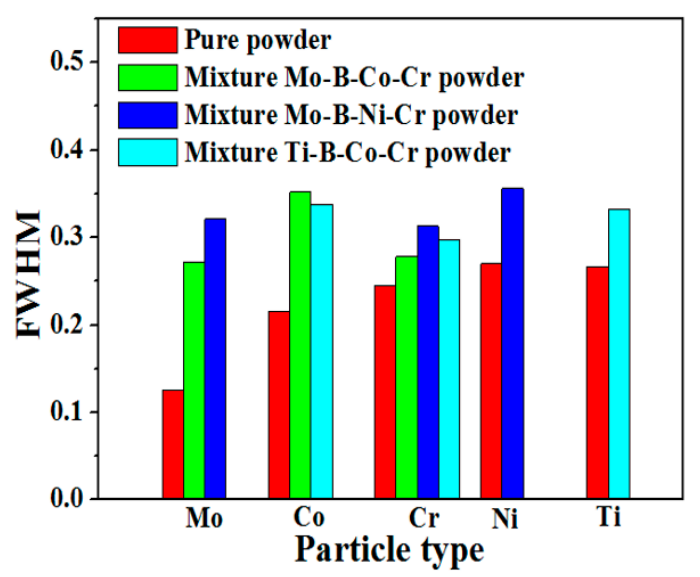

Figure 9. Full widths at half maximum (FWHMs) of $\mathrm{Mo}, \mathrm{B}, \mathrm{Co}, \mathrm{Ni}, \mathrm{Cr}$, and Ti peaks in the pure and mixture powders.

\subsection{X-ray Diffraction Patterns of As-Sprayed Coatings}

In order to clarify the microstructure evolution of as-sprayed coatings, compositional analysis was carried out by XRD. Figure 10 shows the XRD patterns of the in situ synthesis of boride-based $\mathrm{MoB} / \mathrm{CoCr}, \mathrm{MoB} / \mathrm{NiCr}$, and $\mathrm{TiB} / \mathrm{CoCr}$ coatings. The $\mathrm{MoB} / \mathrm{CoCr}$ coating contained $\mathrm{CoMo}_{2} \mathrm{~B}_{2}, \mathrm{CoMoB}$, $\mathrm{CoCr}, \mathrm{Co}$, and $\mathrm{Cr}_{2} \mathrm{O}_{3}$ phases. For the $\mathrm{MoB} / \mathrm{NiCr}$ coating, it was composed of $\mathrm{NiMo}_{2} \mathrm{~B}_{2}, \mathrm{Cr}_{2} \mathrm{O}_{3}, \mathrm{Ni}, \mathrm{Mo}$, $\mathrm{Cr}$, and $\mathrm{NiO}$ phases. The $\mathrm{XRD}$ patterns of the $\mathrm{TiB} / \mathrm{CoCr}$ coating consisted of $\mathrm{TiB}_{2}, \mathrm{TiO}_{2}, \mathrm{Cr}_{2} \mathrm{Cr}_{2} \mathrm{O}_{3}$, and $\mathrm{CoTi}_{2} \mathrm{O}_{5}$ phases. It can be seen from Figure 10 that the ternary/binary borides $\left(\mathrm{CoMo}_{2} \mathrm{~B}_{2}, \mathrm{CoMoB}\right.$, $\mathrm{NiMo}_{2} \mathrm{~B}_{2}$, and $\mathrm{TiB}_{2}$ ) were in situ synthesized in the coatings during spraying at elevated temperature. Meanwhile, there were some pure phases (e.g., $\mathrm{Co}, \mathrm{Ni}, \mathrm{Mo}$, and $\mathrm{Cr}$ ) that did not react with other phases to remain in the coating. However, due to the elevated temperature, oxides were produced in all of the three kinds of coatings. Unlike the report about the XRD patterns of MoB/CoCr coating in Mizuno et al. [16], due to the $\mathrm{MoB} / \mathrm{CoCr}$ spraying the powder was mainly composed of double borides of both $\mathrm{CoMo}_{2} \mathrm{~B}_{2}$ and $\mathrm{CoMoB}$; the $\mathrm{XRD}$ patterns of the $\mathrm{MoB} / \mathrm{CoCr}$ coating were the same as the powders. No other or oxide phases were present in the coating.
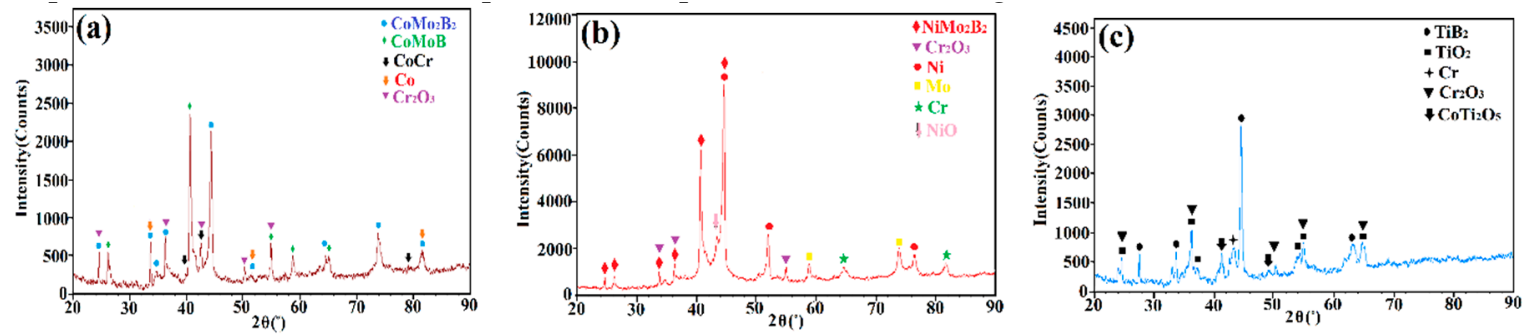

Figure 10. XRD patterns of the boride-based coatings: (a) $\mathrm{MoB} / \mathrm{CoCr},(\mathbf{b}) \mathrm{MoB} / \mathrm{NiCr}$, and (c) TiB/CoCr.

\subsection{Microstructure of As-Sprayed Coatings}

Figures 11-13 show the cross-sectional, backscattered SEM morphologies and compositions of the three kinds of the coatings. The typical lamellar structure of thermal spraying was present in the coatings (as shown in Figures 11b, 12b and 13b). The average porosities of $\mathrm{MoB} / \mathrm{CoCr}, \mathrm{MoB} / \mathrm{NiCr}$, and $\mathrm{TiB} / \mathrm{CoCr}$ coatings were $1.67 \%, 0.811 \%$, and $1.39 \%$, respectively. This clearly illustrates that the $\mathrm{MoB} / \mathrm{NiCr}$ coating presented a denser microstructure than the other two coatings. Furthermore, there were no obvious micro-cracks among the phases in the coatings (as shown in Figures 11b, 12b and 13b) and between the coating and the substrate (as shown in Figures 11a, 12a and 13a). This reveals that the melted Mo-B-Co-Cr, Mo-B-Ni-Cr, or Ti-B-Co-Cr mixture powders (as shown in Figure 6) impacted on the surface of the substrate or pre-coating to form the well-bonded, flattened particles, which could 
fill the pores in the coating and consequently tamp the coating to decrease the porosity. The average thickness of the $\mathrm{MoB} / \mathrm{CoCr}, \mathrm{MoB} / \mathrm{NiCr}$, and $\mathrm{TiB} / \mathrm{CoCr}$ coatings was $315.94 \pm 4.53,290.58 \pm 3.32$, and $325.35 \pm 14.49 \mu \mathrm{m}$, respectively.
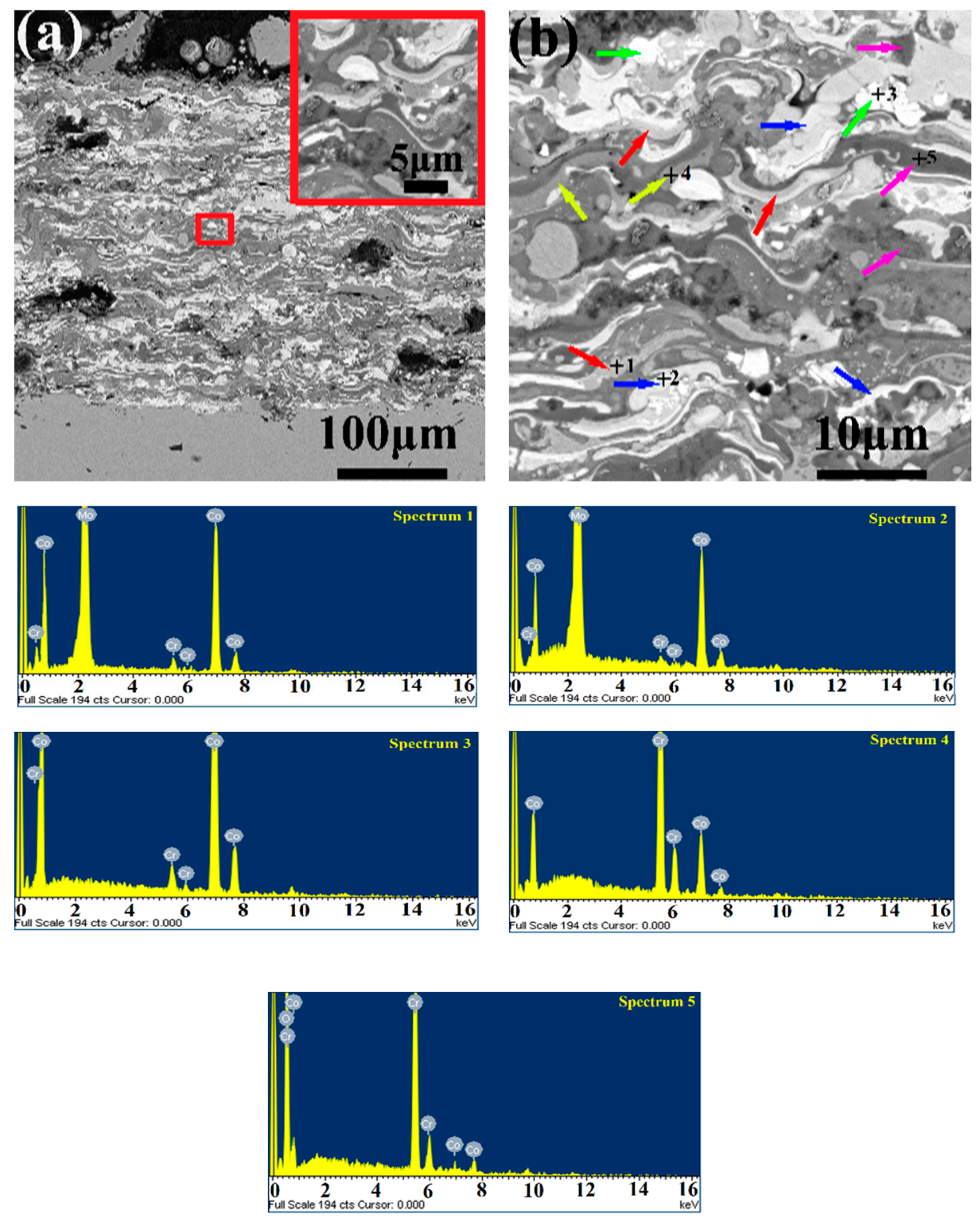

\begin{tabular}{|l|c|c|c|c|c|}
\hline & Mo K(at.\%) & Co K(at.\%) & Cr K(at.\%) & O K(at.\%) & Phase \\
\hline Spectrum 1 & 49.23 & 46.59 & 4.18 & 0 & $\mathrm{CoMoB}$ \\
\hline Spectrum 2 & 59.15 & 39.47 & 1.38 & 0 & $\mathrm{CoMo}_{2} \mathrm{~B}_{2}$ \\
\hline Spectrum 3 & 0 & 96.64 & 3.36 & 0 & $\mathrm{Co}$ \\
\hline Spectrum 4 & 0 & 46.42 & 53.58 & 0 & $\mathrm{CoCr}$ \\
\hline Spectrum 5 & 0 & 0.90 & 37.70 & 61.40 & $\mathrm{Cr}_{2} \mathrm{O}_{3}$ \\
\hline
\end{tabular}

Figure 11. Cross-sectional morphologies and compositions of the $\mathrm{MoB} / \mathrm{CoCr}$ coating: (a) 500x, and (b) $10000 \times$. 

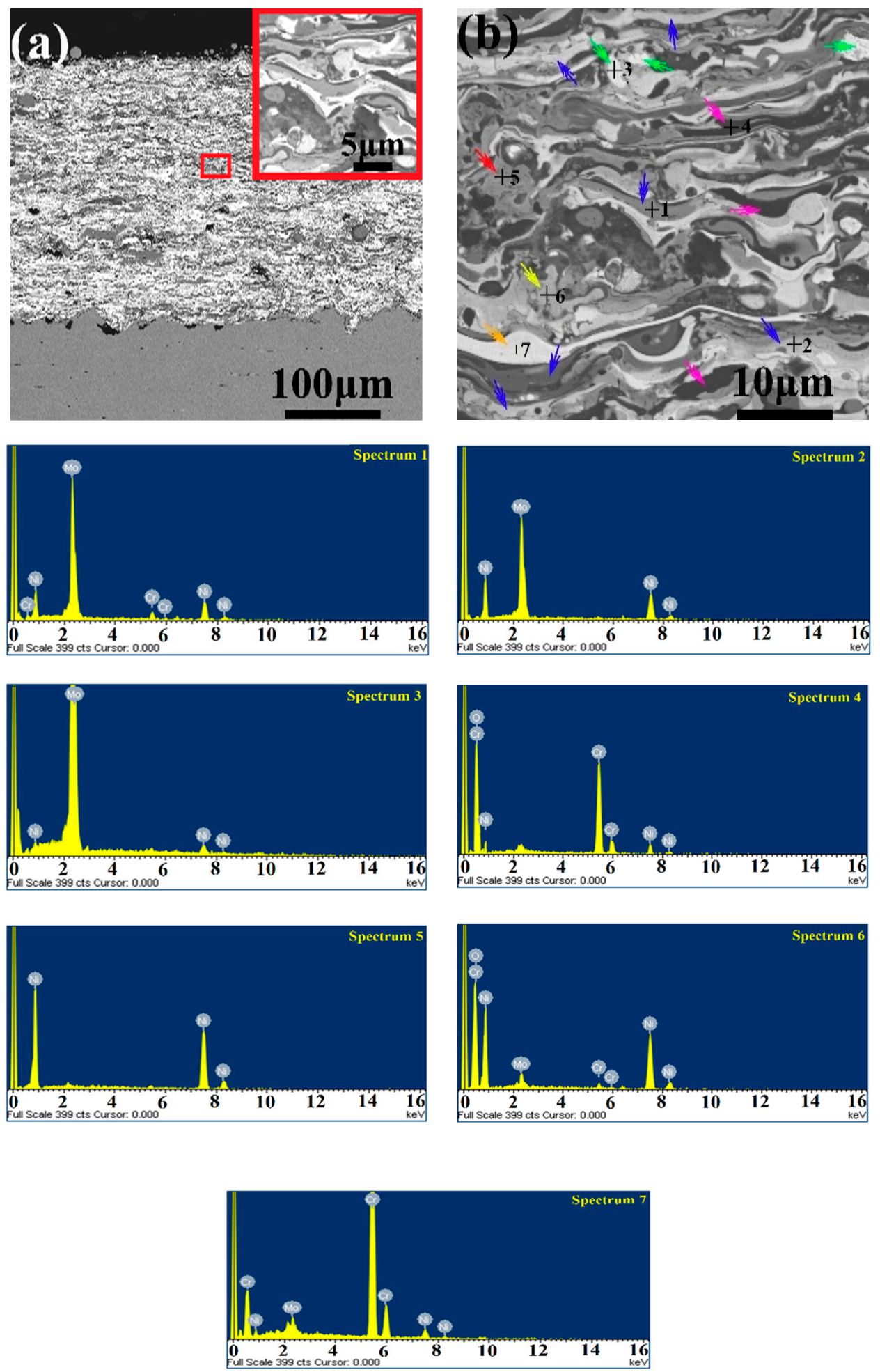

\begin{tabular}{|l|c|c|c|c|c|}
\hline & Mo K(at.\%) & Ni K(at.\%) & Cr K(at.\%) & O K(at.\%) & Phase \\
\hline Spectrum 1 & 62.37 & 30.04 & 7.60 & 0 & $\mathrm{NiMo}_{2} \mathrm{~B}_{2}$ \\
\hline Spectrum 2 & 64.10 & 35.91 & 0 & 0 & $\mathrm{NiMo}_{2} \mathrm{~B}_{2}$ \\
\hline Spectrum 3 & 98.06 & 1.94 & 0 & 0 & $\mathrm{Mo}$ \\
\hline Spectrum 4 & 0 & 2.27 & 35.94 & 61.79 & $\mathrm{Cr}_{2} \mathrm{O}_{3}$ \\
\hline Spectrum 5 & 0 & 100 & 0 & 0 & $\mathrm{Ni}$ \\
\hline Spectrum 6 & 1.71 & 48.78 & 1.35 & 48.16 & $\mathrm{NiO}$ \\
\hline Spectrum 7 & 1.36 & 4.93 & 93.71 & 0 & $\mathrm{Cr}$ \\
\hline
\end{tabular}

Figure 12. Cross-sectional morphologies and compositions of the $\mathrm{MoB} / \mathrm{NiCr}$ coating: (a) $500 \times$, and (b) 10000x. 

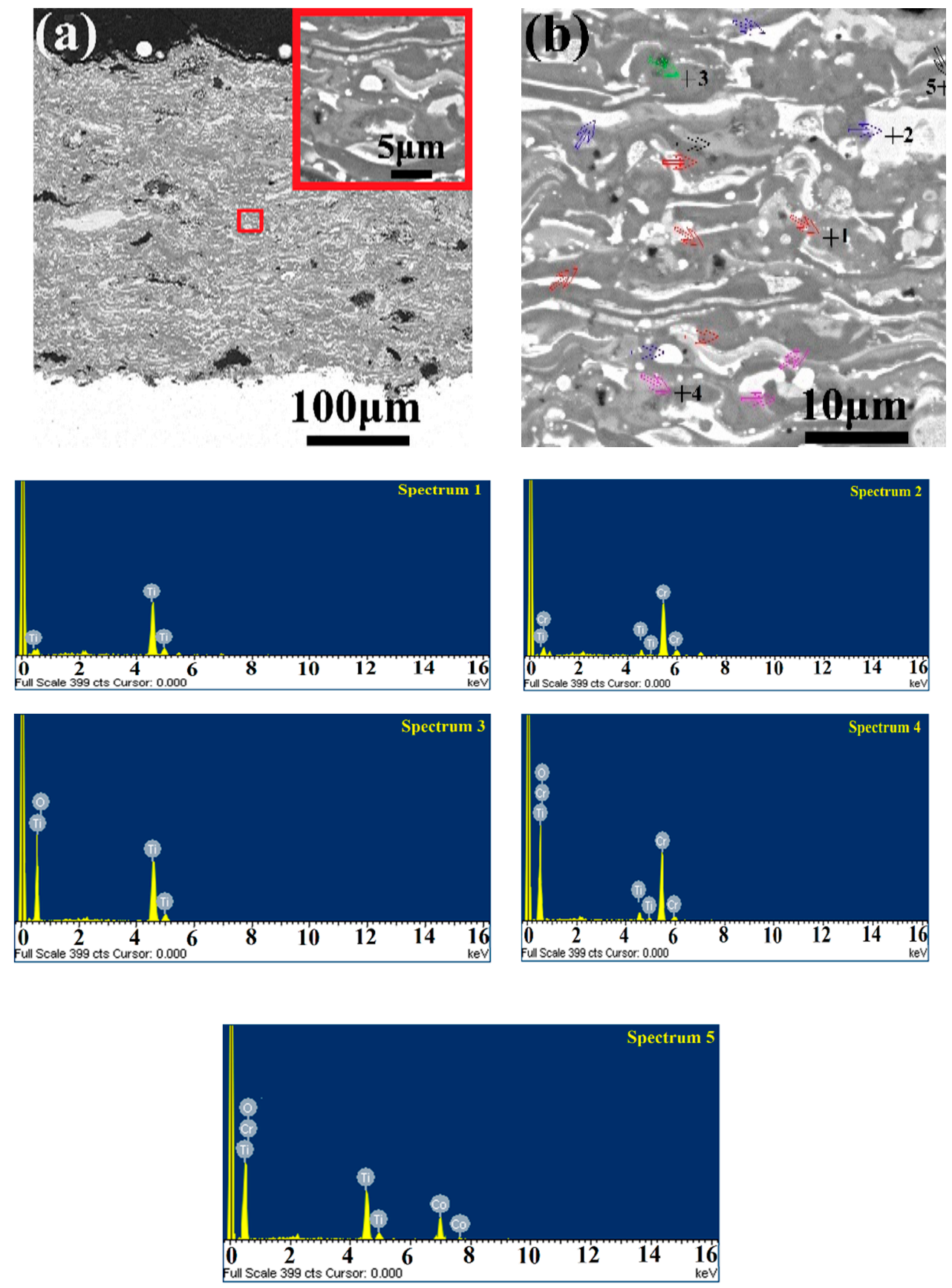

\begin{tabular}{|l|c|c|c|c|c|}
\hline & Ti K(at.\%) & Co K(at.\%) & Cr K(at.\%) & O K(at.\%) & Phase \\
\hline Spectrum 1 & 100 & 0 & 0 & 0 & $\mathrm{TiB}_{2}$ \\
\hline Spectrum 2 & 5.78 & 0 & 94.22 & 0 & $\mathrm{Cr}$ \\
\hline Spectrum 3 & 35.21 & 0 & 0 & 64.79 & $\mathrm{TiO}_{2}$ \\
\hline Spectrum 4 & 3.40 & 0 & 26.21 & 70.39 & $\mathrm{Cr}_{2} \mathrm{O}_{3}$ \\
\hline Spectrum 5 & 27.21 & 11.20 & 0 & 61.59 & $\mathrm{CoTi}_{2} \mathrm{O}_{5}$ \\
\hline
\end{tabular}

Figure 13. Cross-sectional morphologies and compositions of the $\mathrm{TiB} / \mathrm{CoCr}$ coating: (a) 500 $\times$, and (b) $10000 \times$.

In order to clearly determine the compositions of the coatings, the various phases compositions were analyzed by EDS. Like the XRD analysis results, the EDS analysis revealed that CoMoB and $\mathrm{CoMo}_{2} \mathrm{~B}_{2}$ ternary borides (Spectrum 1 and 2, and as indicated by the red and blue arrows, respectively, 
in Figure 11b) were generated in the $\mathrm{MoB} / \mathrm{CoCr}$ coating, but the original pure $\mathrm{Co}$ (Spectrum 3 and as indicated by the green arrow in Figure 11b) was still present in the coating. Furthermore, it was found that a CoCr alloy (Spectrum 4, and as indicated by the yellow arrow in Figure 11b) and $\mathrm{Cr}_{2} \mathrm{O}_{3}$ (Spectrum 5 , and as indicated by the purple arrow in Figure $11 \mathrm{~b}$ ) were formed in the $\mathrm{MoB} / \mathrm{CoCr}$ coating. The same EDS analysis carried out on the $\mathrm{MoB} / \mathrm{NiCr}$ coating revealed that the $\mathrm{NiMo}_{2} \mathrm{~B}_{2}$ phase (Spectrum 1 and 2, and as indicated by the blue double-arrow in Figure $12 \mathrm{~b})$ was in situ synthesized, and oxides $\left(\mathrm{Cr}_{2} \mathrm{O}_{3}\right.$ and $\mathrm{NiO}$ ) (Spectrum 4 and 6, and as indicated by the purple and yellow double-arrow, respectively, in Figure 12b) were formed in the coating. According to EDS analysis, it was found that the $\mathrm{TiB}_{2}$ phase was also in situ synthesized in the $\mathrm{TiB} / \mathrm{CoCr}$ coating (Spectrum 1, and as indicated by the red hollow arrow in Figure 13b), and more types of oxides $\left(\mathrm{TiO}_{2}, \mathrm{Cr}_{2} \mathrm{O}_{3}\right.$, and $\left.\mathrm{CoTi}_{2} \mathrm{O}_{5}\right)$ were generated in this coating. By comparing the cross-sectional morphologies of the three kinds of the coatings (as shown in Figures 11a, 12a and 13a), the boride contents of the coatings were shown in Figure 14. The results showed that the average boride contents of the $\mathrm{MoB} / \mathrm{CoCr}, \mathrm{MoB} / \mathrm{NiCr}$, and $\mathrm{TiB} / \mathrm{CoCr}$ coatings were $33.68 \pm 0.78,41.30 \pm 3.05$, and $36.88 \pm 1.52 \mathrm{vol} \%$, respectively.

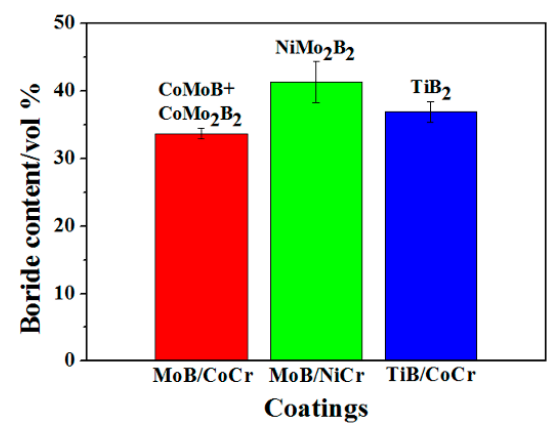

Figure 14. Boride contents of the coatings.

\subsection{Microhardness and Bond Strength of As-Sprayed Coatings}

Figure 15 shows the microhardness of the $\mathrm{MoB} / \mathrm{CoCr}, \mathrm{MoB} / \mathrm{NiCr}$, and $\mathrm{TiB} / \mathrm{CoCr}$ coatings. It can be seen that the microhardness of the $\mathrm{MoB} / \mathrm{NiCr}$ coating $\left(654.45 \pm 23.78 \mathrm{HV}_{0.3}\right)$ was higher than that of the other two coatings, whereas $\mathrm{MoB} / \mathrm{CoCr}$ possessed the lowest at $563.77 \pm 8 \mathrm{HV}_{0.3}$. Furthermore, the microhardness of the three kinds of the coatings was obviously higher than that of the $316 \mathrm{~L}$ stainless-steel substrate $\left(251.16 \pm 21.30 \mathrm{HV}_{0.3}\right)$, and the microhardness of the MoB/NiCr coating was 2.6 times higher than that of the 316L stainless-steel substrate. The reasons for this phenomenon in this study are that the presence of binary or ternary boride phases, with their excellent mechanical properties, can increase the microhardness values in the coatings $[16,28]$. The borides $\left(\mathrm{TiB}_{2}, \mathrm{CoMoB}\right.$, $\mathrm{CoMo}_{2} \mathrm{~B}_{2}, \mathrm{NiMo}_{2} \mathrm{~B}_{2}$ ) were in situ synthesized in the coatings (as shown in Figures 10-13), which would improve the microhardness of the coatings in this study. Meanwhile, the increasing microhardness of the coating can be attributed to the lower coating porosity [13]. Therefore, according to the results of the porosities and boride contents of the coatings, the MoB/ NiCr coating with the most boride content $(41.30 \pm 3.05 \mathrm{vol} \%)$ and lowest porosity $(0.811 \%)$ had the highest microhardness among the coatings.

Figure 16 shows the bond strength of the $\mathrm{MoB} / \mathrm{CoCr}, \mathrm{MoB} / \mathrm{NiCr}$, and $\mathrm{TiB} / \mathrm{CoCr}$ coatings. Compared with the $\mathrm{MoB} / \mathrm{CoCr}$ and $\mathrm{TiB} / \mathrm{CoCr}$ coatings, the MoB/NiCr coating had the highest bond strength $(46.99 \pm 1.20 \mathrm{MPa})$, due to the lowest porosity. However, the bond strength values of the three kinds of the boride coatings were lower than that of the conventional HVOF sprayed cermet coatings (e.g., WC-Co, WC-CoCr, $\mathrm{NiCr}-\mathrm{Cr}_{3} \mathrm{C}_{2}$, etc.) [29-33]. Wang et al. [31,32] and Li et al. [33] reported that the conventional state parameters (e.g., temperature, velocity, and momentum, etc.) were not the direct influencing factors on improving the bond strength of HVOF-sprayed coatings; the more effective mass of the solid phases in a solid-liquid two-phase process were more effective in generating dynamic pressures. (Please check if meaning retained.) In addition, the high bond strength (over $70 \mathrm{MPa}$ ) of HVOF-sprayed WC-Co cermet coatings was owing to the physical bonding and mechanical interlock. 
In this study, the melted mixture powders (Mo-B-Co-Cr, Mo-B-Ni-Cr, and $\mathrm{Ti}-\mathrm{B}-\mathrm{Co}-\mathrm{Cr}$ ) impacted on the surface of the 316L stainless-steel substrate or pre-coating to form flattened particles (as shown in Figures 11-13). No solid phases existed in the coatings, and they could not generate dynamic pressures to form physical bonding during spraying.

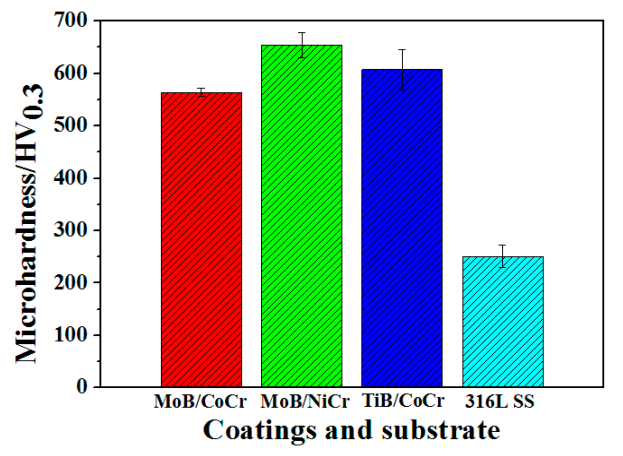

Figure 15. The microhardness of the coatings.

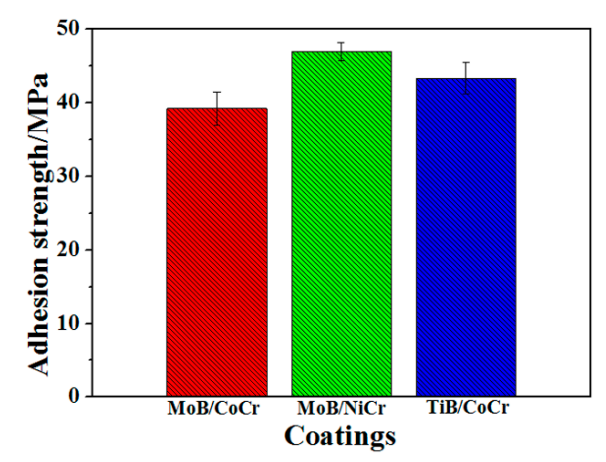

Figure 16. Bond strength of the coatings.

\subsection{Abrasive Wear Behavior of the Coatings}

Figure 17 shows the worn-out surfaces of the boride-based coatings, as compared to 316L stainless steel. It can be seen that grooves (as indicated by the blue arrow), craters (as marked by the green dotted line), and pits (as marked by the yellow dotted line) were observed on the worn track of the coatings. After pin-on-disk testing, deeper grooves and a greater number of craters and pits were observed on the worn track of the $\mathrm{MoB} / \mathrm{CoCr}$ coating, with a rougher worn surface (as shown in Figure 17a); however, the $\mathrm{MoB} / \mathrm{NiCr}$ coating with the smoothest worn surface had shallower grooves and smaller craters/pits (as shown in Figure 17b). Meanwhile, the TiB/CoCr coating showed a medium smooth worn surface. There were many deep and wide grooves on the worn-out surface on the 316L stainless steel (as indicated by the blue arrow in Figure 17d). Due to the low microhardness of 316L stainless-steel, SiC abrasive grits could more easily penetrate the surface of 316L stainless steel, causing deeper and wider grooves and the removal of materials (as indicated by the pink arrow). The weight loss of $\mathrm{MoB} / \mathrm{CoCr}, \mathrm{MoB} / \mathrm{NiCr}$, and $\mathrm{TiB} / \mathrm{CoCr}$ coatings was $11.25 \pm 1.4,6.8 \pm 0.84$, and $8.33 \pm 1.5 \mathrm{mg}$, respectively (as shown in Figure 18). This clearly illustrates that the MoB/NiCr coating had the lowest weight loss values among the coatings. Meanwhile, the weight loss value of the $316 \mathrm{~L}$ stainless-steel substrate $(15.86 \pm 2.3 \mathrm{mg})$ in Figure 18 was more than two times that of the $\mathrm{MoB} / \mathrm{NiCr}$ coating. The reasons for these phenomena in this study are that the microstructure of the coating (e.g., porosity, composition, hard phase content) is the internal factor influencing the wear resistance property. In this study, compared with the other coatings, the lowest porosity $(0.811 \%)$ combined with the greatest amount of in situ synthesized $\mathrm{NiMo}_{2} \mathrm{~B}_{2}$ boride hard phase $(41.30 \pm 3.05 \mathrm{vol} \%)$ in the $\mathrm{MoB} / \mathrm{NiCr}$ coating resulted in the presence of the highest microhardness, which could effectively hinder the cutting and penetration of the $\mathrm{SiC}$ abrasive grits [34]. 

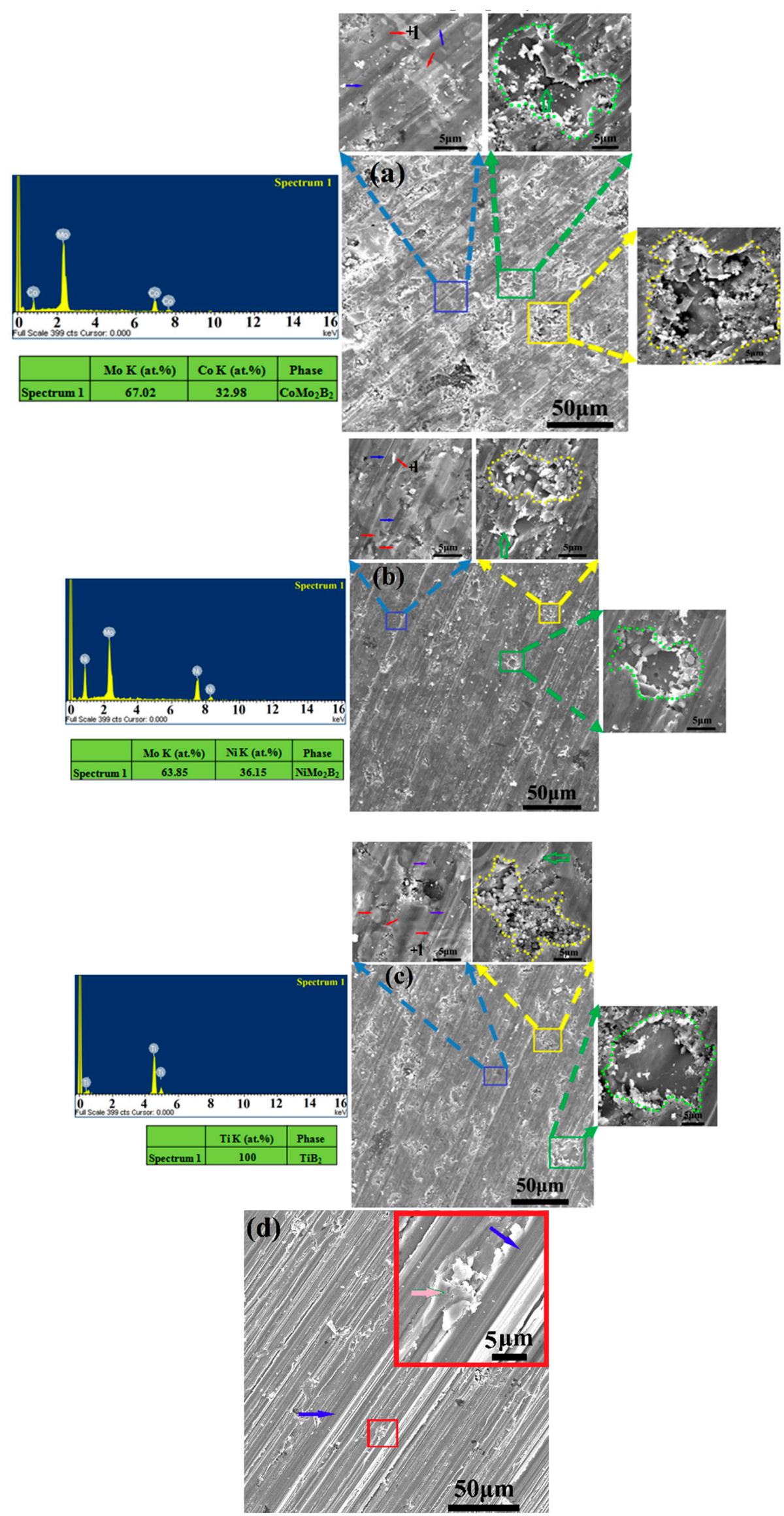

Figure 17. Worn tracks of the boride-based coatings: (a) $\mathrm{MoB} / \mathrm{CoCr},(\mathbf{b}) \mathrm{MoB} / \mathrm{NiCr},(\mathbf{c}) \mathrm{TiB} / \mathrm{CoCr}$, and (d) 316L stainless steel. 


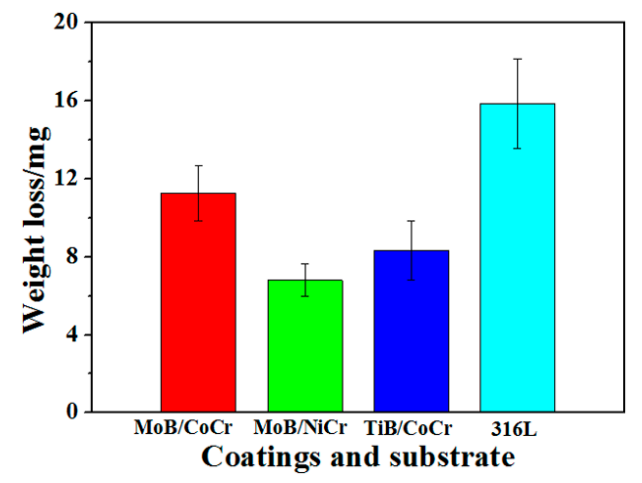

Figure 18. Abrasive weight loss of the boride-based coatings and 316L stainless steel substrate.

Furthermore, the groove formation mechanism of the boride-based coatings in this study was similar to that reported in [34-37]. According to the XRD and EDS analysis results of the boride-based coatings (as shown in Figures 10-13), some metal phases with low microhardness (e.g., Co, Ni, or $\mathrm{Cr}$ ) retained in the coatings could be preferentially and easily removed by $\mathrm{SiC}$ abrasive grits to form grooves. Ji et al. [35] reported that the metal binder phases around the carbide hard phases were preferentially worn off, and the carbide phases exposed to the surface because of the successive removal of binder phase could effectively improve the wear resistance. Kumari et al. [36] also reported that the higher the volume fraction of WC hard phases in the coating, the lower the loss of the softer binder phase; hence, the hard phases are believed to facilitate the formation of fine grooves on the worn out surface of the coatings [37]. In this study, $\mathrm{TiB}_{2}, \mathrm{CoMoB}$ and $\mathrm{CoMo}_{2} \mathrm{~B}_{2}$, or $\mathrm{NiMo}_{2} \mathrm{~B}_{2}$ borides (as indicated by the red arrow and analyzed by EDS in Figure 17) were in situ synthesized in the $\mathrm{TiB} / \mathrm{CoCr}, \mathrm{MoB} / \mathrm{CoCr}$, and $\mathrm{MoB} / \mathrm{NiCr}$ coatings, respectively. The high microhardness of borides could withstand the applied effective load to improve the wear resistance. Hence, the wear resistance of the boride-based coatings was obviously higher than that of 316L stainless steel. Furthermore, the depth and width of grooves on the worn-out surface of the coatings were decreased as the volume fraction of borides increased. Figure 19 shows the average crater content of the worn-out surface of the coatings. This illustrates that the $\mathrm{MoB} / \mathrm{CoCr}$ coating had the highest crater content of the worn-out surfaces among the coatings. The reason for this is that the weak interfacial bonding of various phases caused by the larger pores and higher porosity in the $\mathrm{MoB} / \mathrm{CoCr}$ coating could easily generate more micro-cracks (as indicated by the green hollow arrow) during abrasive wear. The coating materials are easily peeled off to form more craters under the combined action of the propagation of cracks and load. Meanwhile, particles with weak interfacial bonding easily fall off of the coating to form pits. Hence, the highest weight loss of the $\mathrm{MoB} / \mathrm{CoCr}$ coating was expected under such conditions, and $\mathrm{MoB} / \mathrm{NiCr}$ has the best wear resistance property.

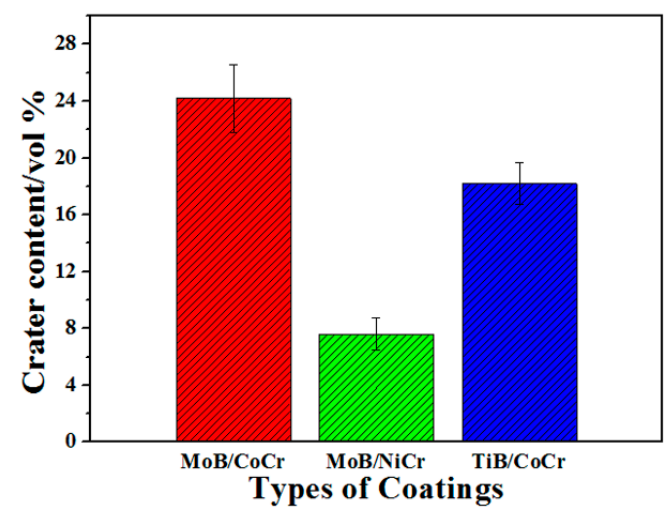

Figure 19. The average crater content of the worn-out surface of the coatings. 


\subsection{Corrosion Behavior of the Coatings}

Figures 20-22 show the SEM images and EDS analysis of the MoB/CoCr, MoB/NiCr, and TiB/CoCr coatings, each immersed in molten zinc at $460{ }^{\circ} \mathrm{C}$ for $360 \mathrm{~h}$. It can be seen that no obvious micro-cracks were generated in any of the three kinds of coatings, and no peeling-off phenomenon occurred between the coating and substrate. According to the EDS analysis for the surface region of the three kinds of the coatings (as indicated by the yellow square), the elemental compositions of the three kinds of coatings after the immersion test were the same as the as-sprayed coatings (as shown in Figures 11-13); this illustrates no presence of zinc or intermetallic compounds in the coatings. The reasons for this were that, due to the excellent corrosion resistance property of ternary and binary borides for molten zinc [13-23], the in situ synthesized borides (e.g., $\mathrm{CoMoB}, \mathrm{CoMo}_{2} \mathrm{~B}_{2}, \mathrm{NiMo}_{2} \mathrm{~B}_{2}$, and $\mathrm{TiB}_{2}$ ) in this study could improve the corrosion resistance of the coatings to molten zinc. Meanwhile, the direction of lamellar microstructure (especially the boride microstructure; as shown in Figures 11-13) of the coatings was perpendicular to that of the molten zinc penetration, which also played an important role in improving the corrosion resistance of the coatings to molten zinc. However, the average thickness of $\mathrm{MoB} / \mathrm{CoCr}, \mathrm{MoB} / \mathrm{NiCr}$, and $\mathrm{TiB} / \mathrm{CoCr}$ coatings after the immersion test was $206.45 \pm 9.00$, $292.10 \pm 17.01$, and $301.32 \pm 24.14 \mu \mathrm{m}$, respectively. Compared with the three kinds of coatings before corrosion, after an immersion test of $360 \mathrm{~h}$, it can be seen that the thickness of the $\mathrm{MoB} / \mathrm{CoCr}$ coating obviously decreased, and that of the $\mathrm{MoB} / \mathrm{NiCr}$ coating was similar to that of the as-sprayed coating. Some researchers have reported that the Co phase in the coating was easily dissolved by molten zinc during the immersion test, which could decrease the thickness of the coating [9-11,16,38]. Hence, in the combined XRD and EDS analysis results of as-sprayed MoB/CoCr coating (as shown in Figures 10 and 11), the Co phase remaining in the coating was dissolved into molten zinc, which led to the coating peel-off and reduction in thickness of the $\mathrm{MoB} / \mathrm{CoCr}$ coating. Meanwhile, due to the higher porosity of the as-sprayed $\mathrm{MoB} / \mathrm{CoCr}$ coating, as compared to the other coatings, the liquid zinc would penetrate into the porosity of the coating to preferentially corrode the Co phase. Tomita et al. [10] and Mizuno et al. [16] reported that the flaws (e.g., cracks or pores) in the coating would be increased due to the surface tension of liquid zinc and the residual stress of as-sprayed coatings during the immersion test. In this study, the average porosity of $\mathrm{MoB} / \mathrm{CoCr}, \mathrm{MoB} / \mathrm{NiCr}$, and $\mathrm{TiB} / \mathrm{CoCr}$ coatings after the immersion test was $4.22 \%, 1.23 \%$, and $2.56 \%$, respectively. It also can be seen that the porosity of the three kinds of coatings was increased after the immersion test-especially the $\mathrm{MoB} / \mathrm{CoCr}$ coatings. Therefore, $\mathrm{MoB} / \mathrm{NiCr}$ coating had the highest corrosion resistance to molten zinc compared to the $\mathrm{MoB} / \mathrm{CoCr}$ and $\mathrm{TiB} / \mathrm{CoCr}$ coatings.

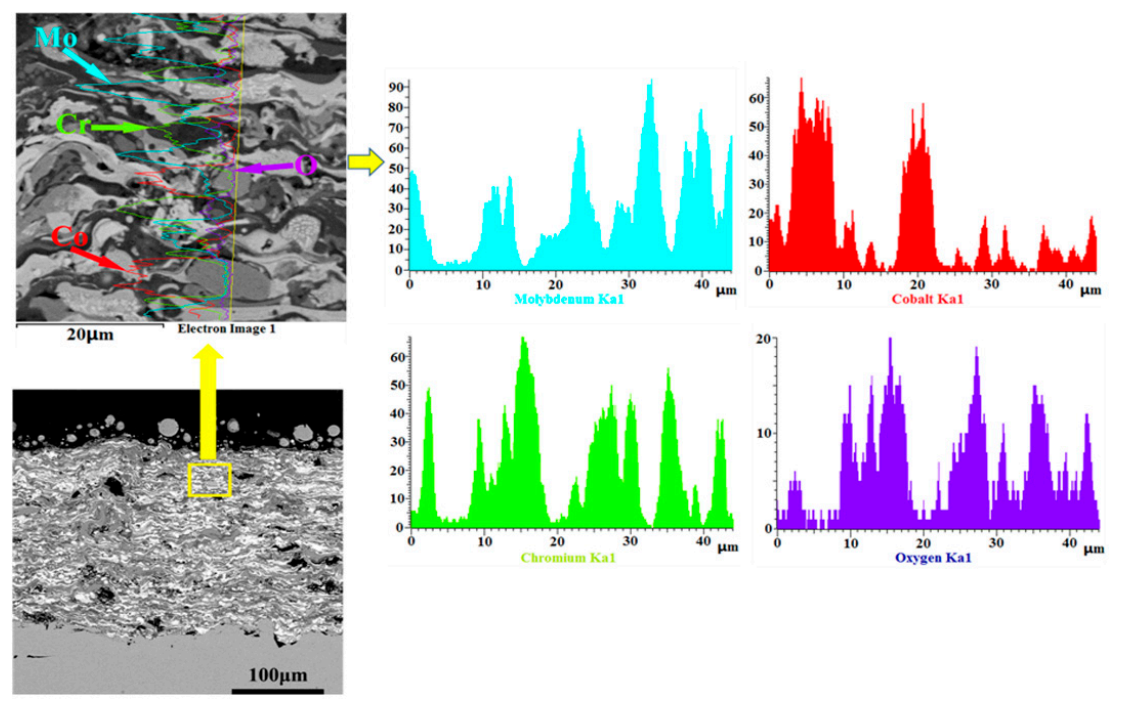

Figure 20. Scanning electron microscopy (SEM) image and energy-dispersive spectroscopy (EDS) analysis of the $\mathrm{MoB} / \mathrm{CoCr}$ coating after an immersion test in molten zinc for $360 \mathrm{~h}$. 


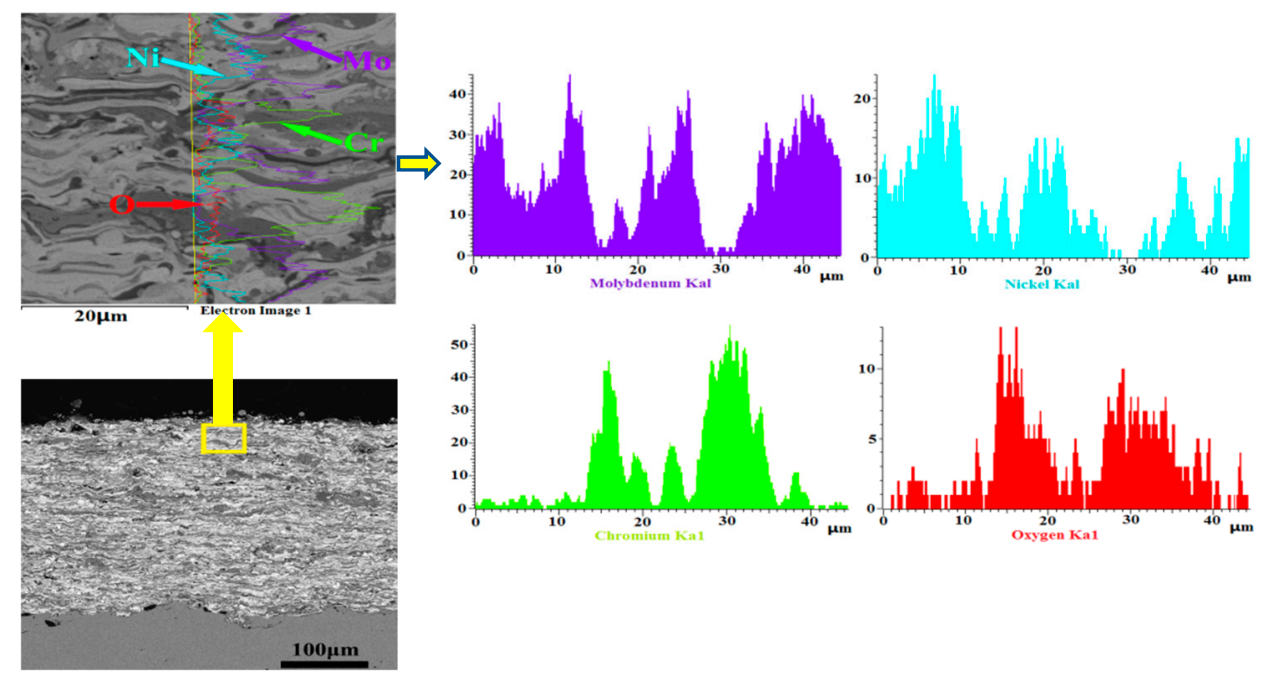

Figure 21. SEM image and EDS analysis of the MoB/NiCr coating after an immersion test in molten zinc for $360 \mathrm{~h}$.
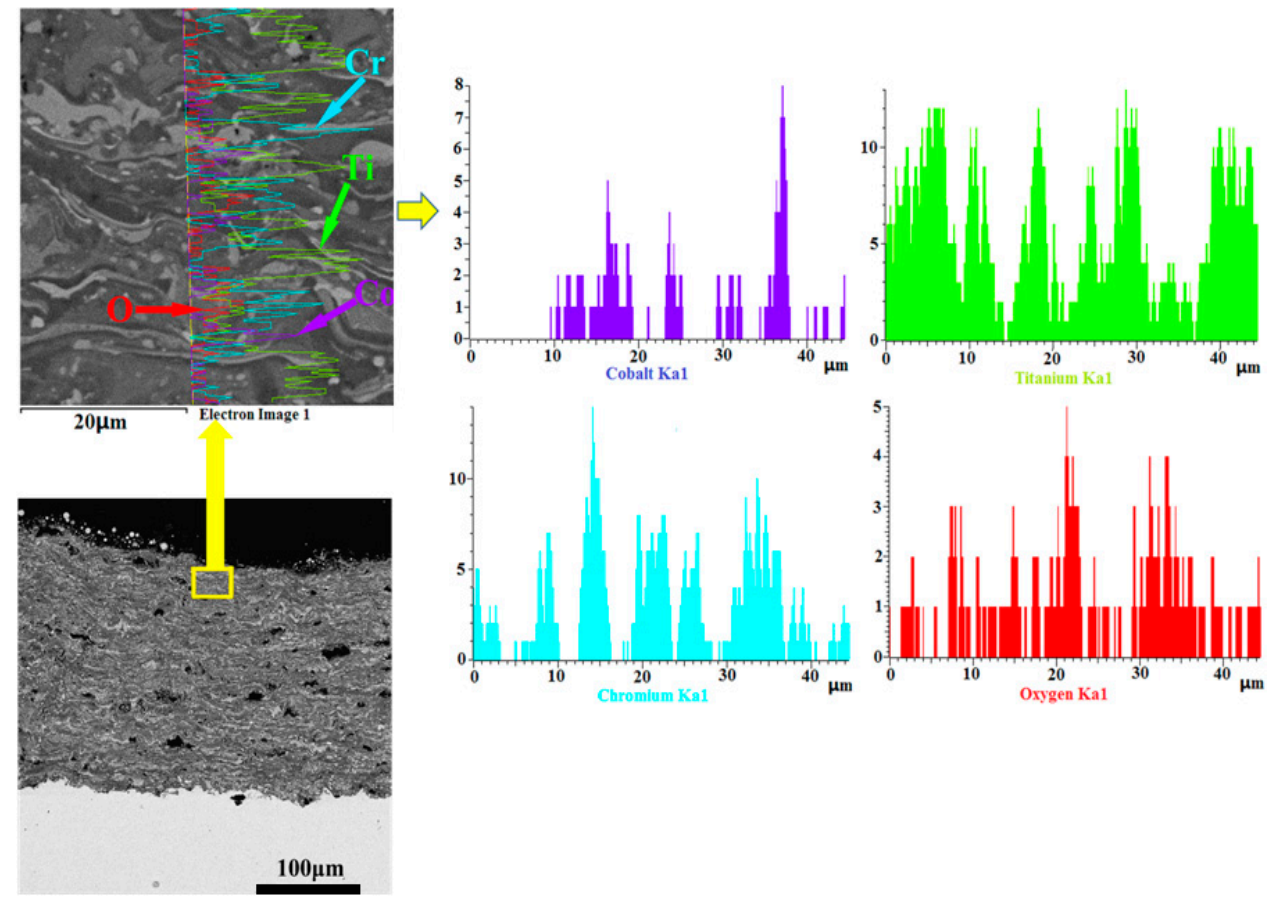

Figure 22. SEM image and EDS analysis of the TiB/CoCr coating after an immersion test in molten zinc for $360 \mathrm{~h}$.

\section{Conclusions}

Three kinds of Mo-B-Co-Cr, Mo-B-Ni-Cr, and Ti-B-Co-Cr mixture powders prepared by a ball milling method were successfully deposited by an HVOF spraying method to form $\mathrm{MoB} / \mathrm{CoCr}$, $\mathrm{MoB} / \mathrm{NiCr}$, and $\mathrm{TiB} / \mathrm{CoCr}$ coatings. The microstructure, mechanical properties, abrasive wear, and corrosion behavior in molten zinc of the coatings were investigated in this study. Based on the results of this study, the following conclusions can be drawn:

- The average porosities of Mo-B-Co-Cr, Mo-B-Ni-Cr, and Ti-B-Co-Cr mixture powders with nearly spherical microstructures were $1.25 \%, 1.31 \%$, and $0.89 \%$, respectively. According to the results of FWHMs of $\mathrm{Mo}, \mathrm{B}, \mathrm{Co}, \mathrm{Ni}, \mathrm{Cr}$, and Ti diffraction peaks in the mixture powders, the pure particles underwent a certain plastic deformation upon high-speed impact during ball milling. 
- The main phase compositions of the Mo-B-Co-Cr, $\mathrm{Mo}-\mathrm{B}-\mathrm{Ni}-\mathrm{Cr}$, and $\mathrm{Ti}-\mathrm{B}-\mathrm{Co}-\mathrm{Cr}$ mixture powders were composed of that of pure powder with no oxidation, interaction, or introduction to impurity.

- The average porosities of the $\mathrm{MoB} / \mathrm{CoCr}, \mathrm{MoB} / \mathrm{NiCr}$, and $\mathrm{TiB} / \mathrm{CoCr}$ coatings with dense microstructures were $1.67 \%, 0.811 \%$, and $1.39 \%$, respectively. The average thickness of the $\mathrm{MoB} / \mathrm{CoCr}, \mathrm{MoB} / \mathrm{NiCr}$, and $\mathrm{TiB} / \mathrm{CoCr}$ coatings was $315.94 \pm 4.53,290.58 \pm 3.32$, and $325.35 \pm 14.49 \mu \mathrm{m}$, respectively.

- From the combined XRD and EDS analysis results, it can be found that the $\mathrm{CoMoB}, \mathrm{CoMo}{ }_{2} \mathrm{~B}_{2}$, $\mathrm{NiMo}_{2} \mathrm{~B}_{2}$, and $\mathrm{TiB}_{2}$ borides were in situ synthesized in the $\mathrm{MoB} / \mathrm{CoCr}, \mathrm{MoB} / \mathrm{NiCr}$, and $\mathrm{TiB} / \mathrm{CoCr}$ coatings, respectively. The average boride contents of the $\mathrm{MoB} / \mathrm{CoCr}, \mathrm{MoB} / \mathrm{NiCr}$, and $\mathrm{TiB} / \mathrm{CoCr}$ coatings were $33.68 \pm 0.78,41.30 \pm 3.05$, and $36.88 \pm 1.52 \mathrm{vol} \%$, respectively.

- The MoB/NiCr coating had the highest microhardness $\left(654.45 \pm 23.78 \mathrm{HV}_{0.3}\right)$ among the coatings, and that was 2.6 times higher than that of the 316 stainless steel substrate. Meanwhile, te $\mathrm{MoB} / \mathrm{NiCr}$ coating had the highest bond strength $(46.99 \pm 1.20 \mathrm{MPa})$.

- The wear mechanism of the $\mathrm{MoB} / \mathrm{CoCr}, \mathrm{MoB} / \mathrm{NiCr}$, and $\mathrm{TiB} / \mathrm{CoCr}$ coatings was grooves, craters, and pits. Compared to the other coatings, the $\mathrm{MoB} / \mathrm{NiCr}$ coating had the smoothest worn surface, with shallower grooves and smaller craters/pits. The groove formation mechanism of the boride-based coatings was that metal phases with low microhardness (e.g., $\mathrm{Co}, \mathrm{Ni}$, or $\mathrm{Cr}$ ) retained in the coatings were preferentially and easily removed by $\mathrm{SiC}$ abrasive grits. The depth and width of grooves on the worn-out surface of the coatings decreased as the volume fraction of borides increased. The $\mathrm{MoB} / \mathrm{CoCr}$ coating had the highest crater content of the worn-out surface among the coatings. The main reason for the crater or pit formation was that the coating materials peeled off due to the weak interfacial bonding between the particles or phases.

- The weight loss of the $\mathrm{MoB} / \mathrm{CoCr}, \mathrm{MoB} / \mathrm{NiCr}$, and $\mathrm{TiB} / \mathrm{CoCr}$ coatings was $11.25 \pm 1.4,6.8 \pm 0.84$, and $8.33 \pm 1.5 \mathrm{mg}$, respectively. The weight loss value of the $316 \mathrm{~L}$ stainless steel substrate $(15.86 \pm 2.3 \mathrm{mg})$ was more than two times that of the MoB/NiCr coating.

- The in situ synthesized borides (e.g., $\mathrm{CoMoB}, \mathrm{CoMo}{ }_{2} \mathrm{~B}_{2}, \mathrm{NiMo}_{2} \mathrm{~B}_{2}$, and $\mathrm{TiB}_{2}$ ) in this study could improve the corrosion resistance of the coatings to molten zinc. After an immersion test for $360 \mathrm{~h}$, the thickness of $\mathrm{MoB} / \mathrm{NiCr}$ coating was similar to that of as-sprayed coating. The $\mathrm{MoB} / \mathrm{NiCr}$ coating had the highest corrosion resistance to molten zinc, compared to the $\mathrm{MoB} / \mathrm{CoCr}$ and TiB/CoCr coatings.

Author Contributions: Conceptualization, X.C.; methodology, X.C. and C.L.; software, S.S.; validation, X.C. and X.B.; formal analysis, X.C.; investigation, X.C.; resources, X.C.; data curation, X.C. and S.X.; writing-original draft preparation, X.C.; writing-review and editing, S.X.; visualization, H.W.; supervision, X.B.; project administration, X.C.; funding acquisition, X.C.

Funding: This research was funded by National Science Foundation of China, Nos. 51561013 and 51861012; the Science Technology Project of Jiangxi Province, No. 20171BAB206007; the Science and Technology Project of Jiangxi Educational Bureau, No. GJJ171062; and the Science Technology Project of Jiujiang City, grant number [2015] No. 64.

Acknowledgments: The authors would also like to thank Haojie Luo for supporting the polyvinyl alcohol (PVA).

Conflicts of Interest: The authors declare no conflict of interest.

\section{References}

1. Wang, W.J.; Lin, J.P.; Wang, Y.L.; Chen, G.L. The corrosion of Fe3Al alloy in liquid zinc. Corros. Sci. 2007, 49, 1340-1349. [CrossRef]

2. Tsipas, D.N.; Triantafyllidis, G.K.; Kiplagat Kipkemoi, J.; Psillaki, P. Degradation behaviour of boronized carbon and high alloy steels in molten aluminium and zinc. Mater. Lett. 1998, 37, 128-131. [CrossRef]

3. Chen, L.; Fourmentin, R.; McDermid, J.R. Morphology and kinetics of interfacial layer formation during continuous hot-dip galvanizing and galvannealing. Metall. Mater. Trans. A 2008, 39, 2128-2142. [CrossRef]

4. Wang, J.H.; Tu, H.; Peng, B.C.; Wang, X.M.; Yin, F.C.; Su, X.P. The effects of zinc bath temperature on the coating growth behavior of reactive steel. Mater. Charact. 2009, 60, 1276-1279. [CrossRef] 
5. Bai, K.; Wu, P. Assessment of the Zn-Fe-Al system for kinetic study of galvanizing. J. Alloys Compd. 2002, 347, 156-164. [CrossRef]

6. Yan, D.R.; Yang, Y.; Dong, Y.C.; Chen, X.G.; Wang, L.; Zhang, J.X.; He, J.N. Phase transitions of plasma sprayed Fe-Al intermetallic coating during corrosion in molten zinc at $640{ }^{\circ} \mathrm{C}$. Intermetallics 2012, 22, 160-165. [CrossRef]

7. Yan, D.R.; He, J.N.; Dong, Y.C.; Li, X.Z.; Zhang, J.X.; Xiao, L.S.; Jing, W.N. The corrosion behavior of plama sprayed $\mathrm{Fe}_{2} \mathrm{Al}_{5}$ coating in molten Zn. Surf. Coat. Technol. 2006, 201, 2662-2666. [CrossRef]

8. Dong, Y.C.; Yan, D.R.; He, J.N.; Zhang, J.X.; Li, X.Z. Degradation behaviour of $\mathrm{ZrO}_{2}-\mathrm{NiAl}_{\text {gradient coatings }}$ in molten Zn. Surf. Coat. Technol. 2006, 201, 2455-2459. [CrossRef]

9. Seong, B.G.; Hwang, S.Y.; Kim, M.C.; Kim, K.Y. Reaction of WC-Co coating with molten zinc in a zinc pot of a continuous galvanizing line. Surf. Coat. Technol. 2001, 138, 101-110. [CrossRef]

10. Tomita, T.; Tatatani, Y.; Kobayashi, Y.; Harada, Y.; Nakahira, H. Durability of WC/Co sprayed coatings in molten pure zinc. Isij Int. 1993, 33, 982-988. [CrossRef]

11. Tani, K.; Tomita, T.; Kobayashi, Y.; Tatatani, Y.; Harada, Y. Durability of sprayed WC/Co coatings in Al-added zinc bath. Isij Int. 1994, 34, 822-828. [CrossRef]

12. Mizuno, H.; Kitamura, J.; Osawa, S.; Itsukaichi, T. Development of Durable Spray Coatings in Molten Aluminum Alloy. In Proceedings of the 2005 International Thermal Spray Conference, Basel, Switzerland, 2-4 May 2005; Lugscheider, E., Ed.; ASM International-Materials Park: Materials Park, OH, USA, 2005.

13. Khan, F.F.; Bae, G.; Kang, K.; Na, H.; Kim, J.; Jeong, T.; Lee, C. Evaluation of die-soldering and erosion resistance of high velocity oxy-fuel sprayed MoB-based cermet coatings. J. Therm. Spray Technol. 2011, 20, 1022-1034. [CrossRef]

14. Takagi, K.I.; Koike, W.; Momozawa, A.; Fujima, T. Effects of $\mathrm{Cr}$ on the properties of $\mathrm{Mo}_{2} \mathrm{NiB}_{2}$ ternary boride. Solid State Sci. 2012, 14, 1643-1647. [CrossRef]

15. Kim, J.S.; Kwon, Y.S.; Lomovsky, O.I.; Dudina, D.V.; Kosarev, V.F.; Klinkov, S.V.; Kwon, D.H.; Smurov, I. Cold spraying of in situ produced $\mathrm{TiB}_{2}-\mathrm{Cu}$ nanocomposite powders. Compos. Sci. Technol. 2007, 67, 2292-2296. [CrossRef]

16. Mizuno, H.; Kitamura, J. MoB/CoCr cermet coatings by HVOF spraying against erosion by Molten Al-Zn alloy. J. Therm. Spray Technol. 2007, 16, 404-413. [CrossRef]

17. Lv, H.P.; Wang, J.; Yan, Y.; An, Q.; Nie, P.; Sun, B. Characterisation of detonation sprayed Mo-Co-Cr-B alloy coatings. Mater. Sci. Technol. 2010, 26, 950-955. [CrossRef]

18. Chen, X.; Zhang, R.Y.; Li, F. Research on microstructure and performance of MoB/CoCr cermet coatings sprayed on 20G steel surface. J. Synth. Cryst. 2011, 40, 266-272.

19. Zhang, J.F.; Deng, C.M.; Song, J.B.; Deng, C.G.; Liu, M.; Zhou, K.S. MoB-CoCr as alternatives to WC-12Co for stainless steel protective coating and its corrosion behavior in molten zinc. Surf. Coat. Technol. 2013, 235, 811-818. [CrossRef]

20. Khan, F.F.; Bae, G.; Kang, K.; Kumar, S.; Jeong, T.; Lee, C.H. Development of cermet coatings by kinetic spray technology for the application of die-soldering and erosion resistance. Surf. Coat. Technol. 2009, 204, 345-352. [CrossRef]

21. Horlock, A.; Mccartney, D.G.; Shipway, P.H.; Wood, J.V. Thermally sprayrd Ni(Cr)-TiB 2 coatings using powder produced by self-propagating high temperature synthesis: Microstructure and abrasive wear behaviour. Mater. Sci. Eng. A 2002, 336, 88-98. [CrossRef]

22. Lotfi, B.; Shipway, P.H.; Mccartney, D.G.; Edris, H. Abrasive wear behaviour of Ni(Cr)-TiB 2 coatings depostied by HVOF spraying of SHS-derived cermet powders. Wear 2003, 254, 340-349. [CrossRef]

23. Chen, X.; Wang, H.T.; Ji, G.C.; Bai, X.B.; Fu, W. Microstructure and properties of TiB ${ }_{2}-\mathrm{Ni}$ coatings with different binder phase contents deposited by HVOF spray process. Rare Met. 2015, 1-9. [CrossRef]

24. Stewart, D.A.; Shipway, P.H.; McCartney, D.G. Microstructure evolution in thermal sprayed WC-Co coatings: Comparison between nanocomposite and conventional starting powders. Acta Mater. 2000, 48, 1593-1604. [CrossRef]

25. Vashishtha, N.; Khatirkar, R.K.; Sapate, S.G. Tribological behaviour of HVOF sprayed WC-12Co, WC-10Co-4Cr and $\mathrm{Cr}_{3} \mathrm{C}_{2}-25 \mathrm{NiCr}$ coatings. Tribol. Int. 2017, 105, 55-68. [CrossRef] 
26. Lv, H.P.; Wang, J.; Zhai, C.S.; Li, F.; Sun, B.D. Study of microstructure, vickers microindentation, and microhardness distribution of HVOF sprayed composite $\mathrm{MoB} / \mathrm{CoCr}$ coating. In Proceedings of the 2007 International Thermal Spray Conference, Beijing, China, 14-16 May 2007; Marple, B.R., Hyland, M.M., Lau, Y.C., Li, C.J., Lima, R.S., Eds.; ASM International: Materials Park, OH, USA, 2007.

27. ASTM G40-15 Standard Terminology Relating to Wear and Erosion; ASTM: West Conshohocken, PA, USA, 1987; Volume 03.02, pp. 243-250.

28. Moghaddam, S.R.; Kaya, F.; Derin, B. Production of Mo2MB2-type (M = Ni, Fe, Co) ternary boride containing alloys by self-propagating high temperature synthesis. J. Eng. Sci. Technol. 2019, in press. [CrossRef]

29. Lin, L.; Li, G.L.; Wang, H.D.; Kang, J.J.; Xu, Z.L.; Wang, H.J. Structure and wear behavior of $\mathrm{NiCr}^{-C r_{3} \mathrm{C}_{2}}$ coatings sprayed by supersonic plasma spraying and high velocity oxy-fuel technologies. Appl. Surf. Sci. 2015, 356, 383-390. [CrossRef]

30. Cho, T.Y.; Yoon, J.H.; Cho, J.Y.; Joo, Y.K.; Kang, J.H.; Zhang, S.H.; Chun, H.G.; Hwang, S.Y.; Kwon, S.C. Surface properties and tensile bond strength of HVOF thermal spray coatings of WC-Co powder onto the surface of 420J2 steel and the bond coats of Ni, NiCr, and Ni/NiCr. Surf. Coat. Technol. 2009, 203, 3250-3253. [CrossRef]

31. Wang, Y.Y.; Li, C.J.; Ohmori, A. Influence of substrate roughness on the bonding mechanisms of high velocity oxy-fuel sprayed coatings. Thin Solid Films 2005, 485, 141-147. [CrossRef]

32. Wang, Y.Y.; Li, C.J.; Ohmori, A. Examination of factors influencing the bond strength of high velocity oxy-fuel sprayed coatings. Surf. Coat. Technol. 2006, 200, 2923-2928. [CrossRef]

33. Li, C.J.; Wang, Y.Y.; Wua, T.; Ji, G.C.; Ohmori, A. Effect of types of ceramic materials in aggregated powder on the adhesive strength of high velocity oxy-fuel sprayed cermet coatings. Surf. Coat. Technol. 2001, 145, 113-120. [CrossRef]

34. Wang, Q.; Luo, S.S.; Wang, S.Y.; Wang, H.; Ramachandran, C.S. Wear, erosion and corrosion resistance of HVOF-sprayed WC and $\mathrm{Cr}_{3} \mathrm{C}_{2}$ based coatings for electrolytic hard chrome replacement. Int. J. Refract. Met. Hard Mater. 2019, 81, 242-252. [CrossRef]

35. Ji, G.C.; Li, C.J.; Wang, Y.Y.; Li, W.Y. Microstructure characterization and abrasive wear performance of HVOF sprayed $\mathrm{Cr}_{3} \mathrm{C}_{2}-\mathrm{NiCr}$ coating. Surf. Coat. Technol. 2006, 200, 6749-6757. [CrossRef]

36. Kumari, K.; Anand, K.; Bellacci, M.; Giannozzi, M. Effect of microstructure on abrasive wear behavior of thermally sprayed WC-10Co-4Cr coatings. Wear 2010, 268, 1309-1319. [CrossRef]

37. Venkateswarlu, K.; Rajinikanth, V.; Naveen, T.; Sinha, D.P.; Ray, A.K. Abrasive wear behavior of thermally sprayed diamond reinforced composite coating deposited with both oxy-acetylene and HVOF techniques. Wear 2009, 266, 995-1002. [CrossRef]

38. Wang, X.B. Corrosion of Co-Cr-W in liqudi zinc. Metall. Mater. Trans. B 2003, 34, 881-886. 